\title{
Osmanlılar'da II. Meşrutiyet Döneminde Yeni Açılan Medreseler ve Din Görevlisi Yetiştirme Çalışmaları
}

\author{
Zeki Salih Zengin*
}

\section{Newly Established Madrasas and the Efforts of Training Religious Commis- sary in the Ottomans' II. Constitutional Era}

The Ottoman education system has changed considerably since the Tanzimat period due to a renewed understanding and a refined structural organization. A new structure of education developed rapidly after the establishment of the Ministry of Education (Maarif-i Umumiye Nezareti) in 1857, and general education was taken entirely into the realm of official schools. With this, madrasas were limited largely to the teaching of religious sciences and to training religious commissary. All of these developments necessitated new regulations in madrasas in order to effectively accomplish their goals. The need for arrangements in the madrasa system had been voiced and even some attempts had been undertaken during the Tanzimat era and Abdulhamit II's reign; despite this, the madrasa had retained its traditional structure. The re-organization of madrasas in accordance with the new education system was made in the Constitutional Period. The re-organization of madrasas had two goals: namely, harmonizing madrasas in accordance with the new educational system, and secondly, improving education quality to better train commissaries. For this purpose, in addition to general madrasas, new madrasas were established with the goal of raising religious commissaries, including prayer leaders (imāms) and preachers (khatīb and wāiz). These madrasas were united under the rubric of Madrasa al-Irshād due to changes made in the subsequent years. However, this attempt failed because of the crisis that took place after the Ottoman State's participation in World War I and disagreements that surfaced about the administrative and financial structure of the madrasa. However, efforts during the given period served as a model for institutions that would open with the same objectives in the Republican period. These efforts and their results are also significant in that they shed light on today's educational problems and offer potential solutions to them. This article aims to present this historical process as much as to reflect upon its implications for today.

Key words: Ottoman State, II. Constitutional Period, Madrasa al-Wāizīn, Madrasa al-Irshād, Madrasa al-A'imma wa al-Khutabā, Religious commissary.

* Prof. Dr., Ankara Yıldırım Beyazıt Üniversitesi İslâmî İlimler Fakültesi (zekisalih55@gmail.com). 


\section{Giriş}

II. Meşrutiyet döneminde yapılan sslah çalışmaları ile geleneksel ilmî ve idarî yapısı yeniden düzenlenen medreseler, teşkilât ve eğitim anlayışındaki değişim kadar sonraki döneme etkileri açısından önemli özellikler taşımaktadır. Değişen bu yapı, kimi özellikleri ile Türkiye Cumhuriyeti’nin yeniden şekillendirdiği din görevlisi yetiştiren kurumlarına da kimi yönleri ile model olmuştur.

Tanzimat sonrası başlayan ve II. Abdülhamid döneminde hız kazanan modern eğitim çalışmaları sonucunda medrese, genel eğitim içindeki ağırlığını zamanla kaybederek kısmen hukuk ve özellikle din görevlisi yetiştirme alanlarına çekilmiştir. Bu gelişme, medresenin bir öğretim kurumu olarak varlık amacını ve yapılanmasını yeniden gözden geçirmesini gerektirmiştir. Gelişmeler karşısında medresenin, müslüman halkın özel hukuk davaları için hukukçu (kadı-nâip) ve din hizmetlerinin yerine getirilmesinde istihdam edilecek görevlilerin yetiştirilmesi olarak iki ana amacı belirmiştir. Bu amaçların gerçekleştirilmesi konusunda II. Meşrutiyet yıllarında medreselerin sslah çalışmaları çerçevesinde;

1. Şerî̀ mahkemelerde görevlendirilecek personelin yetiştirilmesi için zaten mevcut olan kurum Medresetüll-kudât adıyla yeniden düzenlenmiştir.

2. Din görevlilerinin yetiştirilmesi amacıyla ilgili iki tür çalışma yapılmıştır: Öncelikle, İstanbul merkez olmak üzere mevcut medreseler Dârül-hilâfeti'l-aliyye Medresesi adıyla yeniden düzenlenmiştir. Genel Medreseler kapsamında değerlendirebileceğimiz bu medresenin ama$\mathrm{cl}$, esas itibariyle çeşitli seviyelerde din hizmeti verebilecek görevlilerin yetiştirilmesidir.

3. Genel medreselerin dişında vâiz, imam-hatip ve müezzin yetiştirmek amacıyla günümüzdeki meslek okulları karşıllğında meslek medreseleri olarak adlandırabileceğimiz yeni medreseler açılmıştir.

$\mathrm{Bu}$ çalışma içerisinde ele alacağımız ve "yeni" olarak nitelendirdiğimiz kurumlar, Dârü'l-hilâfeti'l-aliyye Medresesi dişında kalan Medresetü'lvâizîn, Medresetü'l-eimme ve'l-hutabâ ve Medresetü'l-irşâd olacaktır. Her ne kadar 1914 yılında Dârü'l-hilâfeti'l-aliyye adıyla yeniden teşkilâtlanan medrese, hem adı hem de ilmî ve idarî yapılanması itibariyle eskisinden farklı olmasına rağmen, esas itibariyle mevcut ve genel nitelikli medreselerin farklı bir ad ve yapı içinde yeniden düzenlenmiş halinden ibarettir. 
Dolayısıyla mevcut kurumun amacını daha etkili biçimde gerçekleştirebilmesi için genel medreseler üzerinde yapılan düzenlemeler, bu dönemdeki faaliyetleri nitelemek için kullanılan islah kavramıyla tamamen örtüşmektedir. Buna karşlık, yukarıda yaptığımız sıralamada üçüncü maddede sözü edilen kurumların, hem amaç hem de yapı itibariyle daha önce var olmayan ve ilk defa bu dönemde açılmış olmaları sebebiyle "yeni" olarak nitelendirilmesi uygun olacaktır.

Çalışmamızda her ne kadar Dârü'l-hilâfeti'l-aliyye Medresesi'ne yer vermeyecek olsak da hem bu kurumun hem de dönem içerisindeki çalışmaların genel özellikleri ile tanıtılmasının yararlı olacağı kanaatindeyiz. Medreselerin ıslahı çalışmaları 1910 tarihli Medâris-i İlmiyye Nizamnâmesi ile başlamakla birlikte asıl ve köklü yenilikler -gayriresmî nitelikli çalışmaların da katkılarıyla- 1914 yılında hazırlanan Islâh-1 Medâris Nizamnâmesi ile gerçekleştirilmiş ve nihayet 1917'de Dârü'l-hilâfeti'l-aliyye Medresesi ile Taşra Medreseleri Nizamnâmesi ile geliştirilmiştir. 1914 yllından itibaren yapılan çalışmalar içerisinde medreselerin özellikle ilmî yapılanmasına bakıldığında, mekteplerde uygulanan öğretim basamaklarına benzer biçimde düzenlendiği görülmektedir. İlköğretime dayalı, iki kademeli (tâlî kısm-1 evvel ve sânî/ibtidâ-yi hâriç ve dâhil), orta öğretim aşamasından sonra yüksek (âlî) kısımlardan oluşan Dârü'l-hilâfeti'l-aliyye Medresesi'nden sonra ihtisas (lisans üstü) öğretime yer verilen Medresetü’l-mütehassısîn bulunmaktadır. Medresenin orta dereceli kısmının öğretim programında meslek dersleri ile paralel ağırlıkta genel kültür derslerine de yer verilirken, yüksek ve ihtisas kısımlarında meslek dersleri çok daha fazla yer bulmuştur. Öğretimin geliştirilmesi konusunda yeni ders kitaplarının hazırlanması, ölçme-değerlendirme usullerinin değiştirilmesi ve yeni öğretim yöntemlerine yer verilmesi esas alınmıştır. Medresenin idaresinde önceleri evkaf-meşihat ikiliği yaşanırken, daha sonra aşamalı olarak meşihat maka$\mathrm{m}$ tek yetkili kılınmıştır. Yapılanmanın İstanbul dışına yaygınlaştırılması ise kısmen gerçekleştirilmiş, Dârü'l-hilâfeti'l-aliyye Medresesi teşkilâtına bağlı olarak, taşrada belirli merkezlerde sadece orta dereceli medreseler açılmıştır. Kararlılıkla sürdürülen bu çalışmaların, Osmanlı Devleti’nin yıkılmasıyla neticelenen I. Dünya Harbi’nin olağanüstü şartlarına rastlaması beklenen başarının elde edilememesindeki en önemli sebeplerden biri olmuştur.

Bu dönemde var olan medreselerin; biri genel, diğeri meslekî nitelikli olarak iki farklı biçimde yapılandırıldığı dikkati çekmektedir. Dârü'l-hilâfeti'laliyye Medresesi adını alan genel medresenin öğretim programı, mesleki eğitim ile birlikte genel kültür derslerini de içerirken, ileride ayrıntılı biçimde 
tanıtacağımız Medresetü'l-vâizîn, Medresetü'l-eimme ve'l-hutabâ ve daha sonra kurulan Medresetü'l-irşâd gibi vâiz, imam, hatip ve müezzin gibi doğrudan din hizmetlerini yerine getirecek görevlilerin yetiştirilmesi ya da kalifiye edilmesi amacını taşıyan kurumlarda ise tamamen meslek derslerine yer verilmektedir. Daha önceki dönemlerde medrese mezunları aynı zamanda din hizmetleri ile ilgili alanlarda da görev yapabilmekte iseler de din görevlileri için müstakil medreselerin kurulması bu döneme özgü bir gelişmedir. Osmanlı döneminde din görevlilerinin yetiştirilmesi konusunda hazırlanmış ya da bu konuya yer verilen önemli çalışmalar bulunmaktadır. ${ }^{1}$

Çalışmamız, Osmanlı Devleti’nin son yıllarında din görevlisi yetiştirmek üzere açılan sözünü ettiğimiz kurumların açılma gerekçeleri, faaliyetleriyle özellikle mevcut çalışmalarda sınırlı bilgi bulunan Cumhuriyet'in kurulmasından hemen önceki son durumlarını, arşiv kaynaklarından da yararlanarak ortaya koymak amacındadır. Diğer taraftan çalışmamız tarihe mal olan kurumların faaliyetlerini ve sonuçlarını ortaya koyarak, günümüzde aynı amacı taşıyan kurumların yapılandırılmasına katkı sağlamayı da hedeflemektedir.

\section{A. Medresetü'l-vâizîn}

Osmanlılar döneminde, halkı dinî konularda aydınlatmak üzere görevlendirilen vâizlerin din ilimleri alanında tahsil görmüş bilgili kimseler arasından seçilmesine önem verilmiştir. ${ }^{2}$ XVI. yüzyıla ait bir kadı beratında, kadıların görevleri arasında tefsir ve hadis konularında bilgisi olmayan cahil kimselerin yanı sıra vaaz etmeye ehliyetli olduğuna dair elinde belgesi olmayanların halkın huzurunda vaaz ve nasihat etmelerine engel olmaları da sayılmıştır. ${ }^{3}$

Vâizlik bir vakfın görevlisi olarak ya da özel bir görevlendirme ile yapıldığı gibi recep, şâban ve ramazan (şuhûr-1 selâse) aylarında ülkeye dağılan medrese talebeleri ve müderrisler tarafından da yerine getirilmiştir. "Cer" adı verilen bu uygulama, talebelerin din hizmetleri konusunda tecrübe kazanmalarına imkân sağladığı gibi dinî bilginin halka ulaştırılmasına da katkı

1 Bu konudaki çalışmalarla ilgili olarak bk. Akgündüz, Osmanlı Döneminde Vâizlik; Başkurt, “Osmanlı’dan Cumhuriyet’e Kürsü Şeyhliği”; Beydilli, Osmanlılar Döneminde İmamlar ve Bir İmamın Günlüğü; Bayraktar, Türkiye’de Vâizlik; Doğan, "Yaygın Din Eğitimi Açısından İkinci Meşrutiyet Dönemine Kadar Vaaz ve Vâizliğin Gelişimine Tarihi Bir Bakış"; Yazıcı, "Osmanlıların Son Döneminde Din Görevlisi Yetiştirme Çabaları Üzerine Bazı Gözlemler”. Bu kaynakların tam künyeleri için bk. Bibl.

2 Akgündüz, Osmanlı Döneminde Vâizlik, s. 17.

3 Uzunçarşılı, Osmanlı Devletỉnin İlmiye Teşkilatı, s. 86. 
sağlamıştır. ${ }^{4}$ Katıldığı huzur derslerinde padişahın takdirini kazanan ve 750 kuruş maaşla Orhâniye Camii vâizliği görevine atanan İhsan Efendi’de olduğu gibi kimi zaman padişahın ihsanı olarak vâiz ataması yapılabilmektedir. ${ }^{5}$ Ramazan ayları, ayrıca vâizlerin görevlendirildiği bir dönem olmuştur. 1861'de sadâretten Maliye Nezâreti’ne gönderilen bir belgede, geçen yıl on dört camide ikindiden sonra halka vaaz etmek üzere şeyh efendiler görevlendirilerek, Ayasofya şeyhine 1000, diğerlerine ise 500'er kuruş ödendiği, bu sene tekrar bu usulün uygulanacağı ancak; otuz iki kişinin başvurması ve bunların "fukarâ-yı sâlihîn"den olmaları sebebiyle meşihatın talebi üzerine tamamına görev verildiği için geçen yılın bütçesine zam yapılması istenmektedir. ${ }^{6}$ Ahmet Hamdi (Akseki), son zamanlarda vâizlerin, yüksek pâyeli medreselere atanacak müderrislerin belirlendiği ruûs imtihanlarında başarılı olamayanlar arasından atandığını, bu sebeple "erbâb-1 iktidardan olan eâzım-1 ulemânın vaaza tenezzül etmediğini” belirtmektedir. ${ }^{7}$

Osmanlı döneminde İstanbul'da cuma namazı kılınan camilerde (selâtin camileri) "kürsü şeyhi, selâtin şeyhi, zeyil meşihatı" ya da "cuma vâizi" adıyla görevlendirilen vâizler, Arapça okunan hutbelerde yer verilen konular yanında diğer dinî hususlarda namazdan sonra halka nasihat etmişlerdir. ${ }^{8}$ Söz konusu bu vâizlerin atanmaları, müderrislere benzer bir usulle şeyhulislâmın teklifi ve padişahın onayı ile yapılmıştır.9

4 Kanal, "II. Abdülhamit Devrinde İstanbul Medreselerindeki Öğrencilerin Cerr Faaliyetleri", s. 262-66.

5 BOA (Başbakanlık Osmanlı Arşivi), BEO, nr. 1770/132691.

6 BOA, A. MKT. MHM, 213/8.

7 Ahmet Hamdi, “Medresetü'l-irşâd”, s. 142.

8 Konu ile ilgili geniş bilgi için bk. Başkurt, “Osmanlı'dan Cumhuriyet’e Kürsü Şeyhliği”, S. 121-22.

9 BOA, A. AMD, 31/20; BOA, A. AMD, 1/2. İstanbul'daki camilerde görevlendirilen kürsü şeylerinin atanma belgelerinden, hangi camilerde cuma namazı kılındığını ya da İstanbul'daki selâtin camilerini tespit etmek mümkün olabilmektedir. Buna göre 1848 yılında atama yapılan ve dolayısıyla cuma namazı kılınan İstanbul'daki toplam yirmi yedi cami sırasıyla şunlardır: Ayasofya-yı Kebîr, Sultan Ahmed, Süleymaniye, Sultan Bayezid, Fâtih, Nuruosmaniye, Sultan Selim, Eyüp, Lâleli, Vâlide Sultan (İstanbul), Şehzade Sultan Mehmed, Vâlide Sultan (Üsküdar), Üsküdar'da Ayazma yakınındaki cami, Bahçe-i İstavroz'daki cami, Vâlide Sultan (Hasköy), Selimiye (Üsküdar), Nusretiye (Tophane Meydanı), Hidayet (Bâb-1 Bahçe), Adliye (Üsküdar'da Şemsi Paşa Sarayı’nda), Tevfîkiye (Karadeniz Boğazı Akıntıburnu), Adliye (Beşiktaş civarında), Râmi Çiftliğiindeki Kışlak-ı Hümâyun'daki cami, Atariye (Çırağan Sarayı civarında), Hamidiye (Mîrgûn), Süleymaniye (Beşiktaş civarında), Vâlide Sultan (Yenibahçe civarında Bîmarhane'de), Cedîd-i Hümâyun (Yahyâ Efendi civarı) Bk., BOA, C. MF. 7594; BOA, A. AMD. nr 1/2. 1849 yılındaki atama belgesinden, bir önceki belgede yer alan son caminin çıkartıldığı, buradan itibaren şu camilerin de eklenerek sayının yirmi dokuza çıktığı görülmektedir: Câmi-i Cedîd-i Hümâyun Mecidiye (Çırağan Sarayı 
Son dönemlerde vâizlik kurumunun olması gereken nitelikten uzaklaşmaya başlayarak bir gelir kapısı olarak görüldüğü, kimi vâizlerin gayriciddi tavırlar gösterdikleri, vaazlarında bazı kişileri doğrudan ya da dolaylı olarak hedef alarak siyasî konulara girdikleri anlaşılmaktadır. II. Abdülhamid dönemine ait bir belgede, "Vâizlerle kürsü şeyhlerinden bazılarının vaaz ve nasihat yerine birtakım mânasız ve ahaliyi güldürecek şeyler söylemek ve taklit yapmak ve şahsiyata vesaireye müteallik doğrudan doğruya veyahut rumuz ve îhâm tarikiyle taarruzât-1 lisâniyyede bulunmak gibi..." davranışlarından söz edilerek bunların engellenmesi gerektiği belirtilmektedir. ${ }^{10}$ Belgede, ayrıca vâizlerin birçoğunun fakir kimseler olup, para kazanmak amacıyla cerre çıkan kimseler olduğundan söz edilerek, görevlerine son verilirken kendilerine bir miktar para verilmesi için meşihat bütçesine hazinenin fukara kaleminden 10.000 kuruş aktarılacağının belirtilmesi dikkat çekicidir. Başka bir belgede ise kimi vâizlerin cehaletinden ve siyasî konulara girdiklerinden bahsedilerek, meşihattan gerekli tedbiri alması istenmektedir:

Ramazân-1 şerif münasebetiyle halka va'z ü nasihat vesilesiyle Bâb-1 Meşîhat'ça mâlûm ve me'zun olmayan hatta behre-i ilmiyyesi bile bulunmayan, başına sarık saran bazı adamların cevâmi-i şerifede va'z ü nasihate kıyam etmekte ve bunların içinde surun haricine çıkarak politikadan vesaireden dahi bahsedenler bulunmakta olduğu ve bunların alelusul camilerden kaldırıldığı mesmu' olmuş olup, kendilerine vâiz sıfatını takınan bu gibi adamların şu hal ve harekette bulunmaları câiz olamayacağından... ${ }^{11}$

Vâizler, idareciler tarafından yeterli ilmî birikime sahip olmaları yanında, halkı yanlış olarak kabul edilen davranışlara sürüklememeleri ve ilgi alanları dışında kalan, özellikle siyasî konulara girmemeleri hususlarında denetlenmişler, kusurlu görülenler görevden alınarak cezalandırılmışlardır. Meselâ Manastır'da Besim Paşa Camii’nde yaptığ 1 vaazda Ehl-i sünnet ve İmâm-1 Âzam hakkında münasebetsiz konuşarak dil uzatan Denizlili Şâkir

civarında), Câmi-i Cedîd-i Hümâyun (Hırka-i Saâdet Dairesỉnde), Câmi-i Cedîd-i Hümâyun (Ortaköy'de). Bk.BOA, A.DVN, 48/2. 1867 yılını da kapsayan bir defterden ise bunlara Rumelihisarı, Mihrimah Sultan ve Vâlide Sultan (Dolmabahçe'de) camilerinin eklenerek sayılarının otuz ikiye çıktığı (Bk.BA, Dîvân-ı Hümâyun Ruûs Defterleri, Medâris-i Âsitane-i Âliye, nr. 224), daha sonra Aksaray Vâlide Sultan Camii'nin eklenmesiyle otuz üçe ulaştığı anlaşılmaktadır. Bk. Cerîde-i İlmiyye, 8, s. 516-17; İlmiyye Salnâmesi, s. 138.

10 BOA, Y.PRK. BŞK, 25/85.

11 BOA, Y.EE, 5/119. 
Efendi, müftünün ve ulemanın tepkisi sonucu meşihatın da onayı ile görevinden alınarak memleketine gönderilmiştir. ${ }^{12}$ Benzer biçimde Beşiktaş Camii’nde vaaz eden Kemahlı İbrâhim Hakkı Efendi uygunsuz ifadeler kullandığı gerekçesiyle önce Yıldız Sarayı’nda sorgulanmış, ardından yine meşihatın onayı ile aynı biçimde cezalandırılmıştır. ${ }^{13}$ Yine Bursa'da vaaz ettiği sırada uygunsuz beyanlarda bulunduğu gerekçesiyle hakkında tahkikat başlatılan Erzurumlu Şevket Efendinin isterse Trabzon'da ikamet etmek, isterse memleketi Erzurum'a gönderilmek üzere tercih yapabileceği belirtilmektedir. $^{14}$

II. Meşrutiyet yıllarında oldukça hareketli olan siyasî ortamın din alanını da etkilediği görülmektedir. ${ }^{15} 1909$ yılında Bebek Camii'nde vaaz eden Müderris Hacı Süleyman Efendi'nin meşrutî idarenin yararından bahsettiği sırada, cemaatten bir kişinin tepki gösterip, dışarı çıkarak vâiz hakkında kötü söz söylemesi ve diğerinin müdahale etmesi üzerine konu adliyeye intikal etmiştir. ${ }^{16}$ Bu gibi olayların sıkça görülmesi, vaazlarında siyasî partilerin görüşlerini ve politikalarını dinî açıdan gerekçelendirmeye ya da muhalefet etmeye çalışan vâizlerin haklı olarak tenkit edilmesine sebep olmuştur. Ahmed Necâti, bazı ulemânın kendi fırkaları (partileri) lehine âyet ve hadisleri yorumlayarak dinî, siyasî görüşlerine alet ettiklerini belirterek durumdan şikâyet etmektedir. ${ }^{17}$ Yine, Ödemiş’te müderrislik yapan Mustafa Hakkı, özellikle son yarım asırda halka doğruyu gösteren vâizlerin yerini menfaatperest ve cahil vâizlerin aldığından şikâyet ederek bunların, halkı asılsız ve anlamsız nasihatlerle sanattan ve ticaretten soğuttuklarını, böylece vâizliğin itibarının düşmesine sebep olduklarını ifade etmektedir. ${ }^{18}$

$\mathrm{Bu}$ tür problemlerin giderilmesi amaciyla vâizlere yol gösterici mahiyette yazıların da kaleme alındığı görülmektedir. Meselâ az önce tenkitlerine yer verdiğimiz Mustafa Hakkı, diğer bir makalesinde, vâizlerin öncelikle görevlerinin kutsallığına inanmaları, yumuşak ve sade bir dille hitap etmeleri, vaazlarında birlik ve bütünlüğü sağlayıcı konulara yer vermeleri, âyet ve hadislere bağlı kalarak hurafe ve bâtıl inançlara itibar etmemeleri gerektiğini

\footnotetext{
12 BOA, Y.PRK. BŞK, 30/19.

13 BOA, Y.PRK. MŞ, 6/2.

$14 \mathrm{BOA}, \mathrm{ZB}, 350 / 123$.

15 Krş. Doğan, "Yaygın Din Eğitimi Açısından İkinci Meşrutiyet Dönemine Kadar Vaaz ve Vâizliğin Gelişimine Tarihi Bir Bakış”, s. 266-68.

16 BOA, DH. EUM. THR, 91/15.

17 Ahmet Necati, "Ulemâ-i Kiramdan Bir Rica", s. 3009.

18 Mustafa Hakk1, “Ulemâ-i İslâmiyye ile Hasbihal”, s. 796.
} 
ifade etmektedir. Ayrıca o, sözlerinin etkili olabilmesi için öncelikle anlattıklarını kendilerinin yaşamaları gerektiği hususunda vâizlerin dikkatini çekmektedir. ${ }^{19}$ Mustafa Sabri de ramazan dolayısıyla taşraya gidecek talebelere, vaazlarında bilmedikleri konulara girmemelerini, halka meşrutî idarenin faziletlerini ve bu idare tarzının İslâmî açıdan üstünlügünü anlatmalarını istemektedir. ${ }^{20}$ Beyânülhak dergisinde yayımlanan ancak yazarı belirtilmeyen diğer bir makalede de vâizlerin anlatacakları konuya hâkim olmaları, halkın zihninde şüpheler ortaya çıkaracak veya aklın kabul etmeyeceği konularla uğraşmak yerine, onları çalışmaya yöneltecek ve dinin özünü öğretecek konuların üzerinde durmaları istenmektedir. Makalede ayrıca vâizlerin, hitap edecekleri topluluğun maddî ve mânevî durumlarına göre tavır almaları gerektiği konusuna yer verilmiştir ki esasen bu kural, yapılan nasihatin sonuç verebilmesi açısından fevkalâde önem taşımaktadır. ${ }^{21}$ Ahmet Hamdi de vâizlerin görevinin sadece halka dinî bilgileri öğretmek olmadığını, aynı zamanda onları birlik ve beraberliğe, çalışmaya davet ederek mânevî yönden olduğu kadar iktisadî yönden gelişmeye de teşvik etmek olduğunu belirtmektedir. ${ }^{22}$

Konu 1912 yılında Meclis-i Vükelâ’da görüşülerek, amaçları dışında konulara giren vâizlerin meşihatın da onayı ile engellenmesi gerektiğine karar verilmiş, ardından da bir nizamnâme hazırlanmıştır. ${ }^{23}$ Nizamnâmede, vâizlerin İstanbul'da ders vekâleti, taşrada ise müftüler tarafından verilecek ve vaaza izinli olduğunu gösteren bir belgeye sahip olmaları gerektiği belirtilerek, halk arasında ayrıllğa sebep olabilecek mahiyette vaaz edenlerin cezalandırılacağı ifade edilmektedir.

II. Meşrutiyet döneminde, nitelikli vâizlerin yetiştirilmesi amacıyla Medresetül-vâizîn ve Medresetü'l-eimme ve'l-hutabânın kurulması, din eğitimi ve öğretimi konusuna verilen önemi gösterir. Ayrıca bu çalışmaları, medreselerin mevcut yapısının, içinde bulunulan dönemdeki ve toplumdaki gelişmeler karşısında yeterli olamadığının kabul edilmesinin bir sonucu olarak değerlendirmek mümkündür.

Nizamnâmesi 1914 yılında yayımlanmış olsa da Medresetü'l-vâizîn'in kuruluşu II. Meşrutiyet döneminin ilk yıllarına kadar uzanmaktadır. 1909 yılında medreselerin ıslahı konusunda çalışmalar yapmak üzere kurulan

19 Mustafa Hakk1, "Vâizîn-i Kirâm İçin Vezâif-i Mühimme”, s. 854-57.

20 Mustafa Sabri, “Talebe-i Ulûma”, s. 764-68.

21 "Vâizlere İhtar", s. 877-79.

22 Ahmet Hamdi, "Medresetü'l-irşâd”, s. 143.

23 BOA, MV, 163/79; "Cevâmi' ve Mesâcîd-i Şerîfede Vaaz ve Nasihat Edecek Ulema

Hakkında Nizamnâme”, s. 375; Cerîde-i İlmiyye, 1, s. 18-19. 
Islâh-1 Medâris Encümeni, diğer çalışmaları yanında, vâizlerin yetiştirileceği ayrı bir şubenin kurulmasını kararlaştırarak programını hazırlamıştır. ${ }^{24}$ Konu 1910 yllında Meclis-i Vükelâ’da görüşülerek ehliyetli vâizler yetiştirmek amacıyla programında din ilimleri yanında diğer derslere de yer verilecek, Cem 'iyyet-i Hayriyye-i İlmiyye'ye bağlı ve ulemâdan on iki kişiden müteşekkil Cem 'iyyetü'l-ilim ve'l-irşâd adlı bir heyet tarafından idare edilecek İstanbul'da yeni bir medresenin kurulmasına karar verilmiştir. Karar daha sonra tekrar düzenlenmiş, nihayet Evkaf Nezâreti’ne bağlı olarak 28 Aralık 1912 yılında açılmıştır. ${ }^{25}$

İstanbul Müftülügü Şer'iyye Sicilleri Arşivi’nde, medresenin ilk kurulduğu yıllara ait kayıtların bulunduğu defterde medrese ile ilgili bilgiler bulunmaktadır. ${ }^{26}$ Talebelerin fotoğrafları, nüfus ve ikamet bilgilerinin bulunduğu defterin baş tarafındaki ilk birkaç talebenin, derslerde aldıkları notların kaydı tutulmuşsa da daha sonrakilerde bu kayıtlara yer verilmemektedir. Öğretim süresi dört yıl olan medreseye talebeler Arapça ibare, sarf, nahiv, mantık, âdap, meânî, beyan ve bedî̀ derslerinden yapılan imtihana göre kabul edilmektedir. Defterde ilk üç yılda okutulan derslere yer verilmekle birlikte 1915 yılında yapılan sene sonu imtihanlarında üçüncü sinıftan dördüncü sınıfa geçen talebelerle ilgili bilgiler de bulunmaktadır. Bu durum, medresenin ilk kuruluşu esnasında üç yıl süreli olarak planlandığını; ancak 1914 yılında hazırlanan nizamnâme ile bu süreye bir yıl daha ilâve edildiğini göstermektedir. Söz konusu defterde birinci, ikinci ve üçüncü sinfflara ait programda şu derslere yer verilmiştir:

24 BOA, MV, 143/38.

25 "Medresetü'l-vâizîn”, s. 194; Ergün, "II. Meşrûtiyet Döneminde Medreselerin Durumu ve Islahat Çalışmaları”, s. 86. Medresetü’l-vâizîn’in ilk binası olan Vânî Efendi, diğer adı ile Vâlide Sultan Medresesi’nin asıl yeri Eminönü Bahçekapı'da iken 1909 yılında Ayasofya civarında Soğukçeşme'deki Zeynep Sultan Camii'nin yanına taşınmıştır. Bina günümüzde Osmanlı Araştırmaları Vakfı tarafından kullanılmaktadır. Bk. Kütükoğlu, XX. Asra Erişen İstanbul Medreseleri, s. 59; Kurşun v.dğr., Medâris-i İstanbul, I, 101.

26 Medresetül-irşâd Vâizîn Şubesi Talebe Efendilerin Künye Defteri, nr. 2343. Başlığına bakıldığında defterin, daha sonra kurulan Medresetü'l-irşâd'ın Vâizîn Şubesi'ne ait olduğu izlenimi uyanmaktadır; ancak defterin içindeki kayıtların tarihlerinden defterin 1912 yılından itibaren tutulduğu anlaşılmaktadır. Medreseye ilk kaydı yapılan talebe olan Nevşehirli Mehmed Enver Efendi’nin kayıt tarihi 1327 (1911/1912) olarak tespit edilmektedir. Yine, yapılan imtihan sonuçlarıyla ilgili bilgiler 19121915 yıllarını kapsamaktadır. Bu bilgiler, söz konusu defterin, Medresetü'l-irşâd'ın kuruluşuyla değil, Medresetüll-vâizîn’in ilk kurulduğu tarihten itibaren tutulduğunu göstermektedir. Defterde kaydı bulunan 259 talebenin sadece ilk dönemde değil, Medresetü'l-irşâd'ın kuruluşundan sonra kaydedilenlerin toplam sayısı olduğu anlaşılmaktadır. 
1. Sınıf: Tefsir, hadis, ilm-i kelâm, fikıh, siyer ve târîh-i İslâm, târîh-i edyân, edebiyyât-1 Arabiyye, edebiyyât-1 Osmâniyye, ilm-i ruh, lisân-1 Fârisî, mâlûmât-1 hukūkıyye, coğrafya-yı İslâm ve Osmânî, hesap, hüsn-i hat ve imlâ.

2. Sınıf: Tefsir, hadis, ilm-i kelâm, fıkıh, usûl-i fıkıh, siyer ve târîh-i İslâm, târîh-i edyân, târîh-i Osmânî, târîh-i umûmî, edebiyyât-1 Arabiyye, edebiyyât-1 Osmâniyye, ilm-i ruh, lisân-1 Fârisî, mâlûmât-1 hukūkıyye, coğrafya-yı İslâm ve Osmânî, hesap, cebir, hendese ve hifzissihha.

3. Sınıf: Tefsir, hadis, ilm-i kelâm, fıkıh, târîh-i edyân, edebiyyât-1 Arabiyye, edebiyyât-ı Osmâniyye, usûl-i fıkıh, hıfzıssıhha, felsefe, hikmet-i tabîiye, kimya, mevâlîd-i selâse, hitabet ve mev'iza ve hey'et. $^{27}$

İlk açıldığında orta dereceli bir medrese olarak tasarlanmasına rağmen oldukça ağır bir program uygulanan Medresetü'l-vâizîn'deki talebeler başarısız duruma düşmüşlerdir. Medresenin idareci ve öğretim kadrosunun yetersizliği ile gerekli disiplinin sağlanamamış olması başarısızlı̆̆ın diğer sebepleri olarak ileri sürülmüştür. ${ }^{28} 1914$ yılında Evkaf nâzırlığı görevine atanan Mustafa Hayri Efendi, nizamnâmesini hazırladığı medreseyi yeniden düzenlemiştir. ${ }^{29}$ Buna göre önceden olduğu gibi Evkaf Nezâreti’ne bağlı, dört yıllık yüksek dereceli medrese olarak düzenlenen Medresetü’lvâizîn'in kuruluş amacı, nizamnâmesinin ilk maddesinde, "Kur'an'ın yüce hükümleri, Hz. Peygamber'in sünneti dairesinde güzel ahlâkı ve İslâm’ın medeniyetin ilerlemesine hizmet eden hükümleri ile sosyal düzenin kurulmasına yardımcı olacak güzel öğütlerini insanlara öğretecek yol gösterici ve davetçilerin yetiştirilmeleri ${ }^{30}$ " olarak ifade edilmiştir. Şimdilik gündüzlü olarak öğretime devam eden; ancak ileride yatılı hale getirilmesi planlanan medresenin idaresi, tayin edilecek bir müdür tarafından gerçekleştirilecektir.

27 İstanbul Müftülügü Şer'iyye Sicilleri Arşivi, Medresetü'l-irşâd Vâizîn Şubesi Talebe Efendilerin Künye Defteri, nr. 2343.

28 "Medresetü'l-vâizîn”, s. 194-95.

29 "Medresetü’l-vâizîn Nizamnâmesi”, VI, 212-15; Medresetüll-vâizîn Nizamnâme ve Tâlimatnâmesi, s. 7-13; BOA, MV, 233/98.

30 "Ahkâm-1 âliye-i Kur'aniye ve sünen-i seniyye-i nebeviye dairesinde mekârim-i ahlâkiyeyi ve din-i mübin-i İslam’nn terakkiyât-1 medeniyeye hâdim hükm-i celile ve mevâiz-i hasene-i içtimâiyesini neşr ü tamim edecek erbâb-1 İrşâd ve duât yetiştirmek maksadiyla...” 
Medrese için 1915 yılında hazırlanan programda derslerin hangi sınıflarda kaç saat ve kimler tarafından okutulacağı belirtilmiştir. ${ }^{31}$ Amacı, halkı dinî konularda aydınlatacak vâizlerin yetiştirilmesi olan bu medresenin programında, din ilimleri ile birlikte matematik, fen, coğrafya ve tarih gibi derslerin yanında ilm-i içtimâ (sosyoloji) ve terbiye, felsefe gibi derslere de yer verilmesi, talebelerin hitabettikleri toplumu tanımalarına ve görevlerinde başarılı olmalarına yardımcı olabilmesi açısından oldukça isabetlidir. Medresede ders vermek üzere görevlendirilenler arasında Ziya (Gökalp), Ahmed Refik (Altınay), Ma'rûf er-Rusâfî, Selim Sırrı (Tarcan), Abdurrahman Şeref, Yusuf Akçura ve Mithat Cemal (Kuntay) gibi devrin tanınmış simalarının olması dikkat çekicidir (Tablo 1).

Tablo 1: Medresetü’l-vâizîn'de 1915 Yilında Uygulanan Ders Programı

\begin{tabular}{|c|c|c|c|c|c|}
\hline & $\begin{array}{l}\text { Günler/ } \\
\text { Dersler }\end{array}$ & 1. Ders & 2. Ders & 3. Ders & 4. Ders \\
\hline \multirow{6}{*}{$\begin{array}{c}1 . \\
\text { Sinif }\end{array}$} & Cumartesi & $\begin{array}{l}\text { Hadîs-i şerif } \\
\text { Şükrü } \\
\text { Efendi }\end{array}$ & $\begin{array}{l}\text { Coğrafya-i } \\
\text { umûmî } \\
\text { Ali Tevfik Bey }\end{array}$ & $\begin{array}{l}\text { Târîh-i umûmî } \\
\text { Ali Tevfik Bey }\end{array}$ & $\begin{array}{l}\text { Târîh-i } \\
\text { Osmânî } \\
\text { Atâ Bey }\end{array}$ \\
\hline & Pazar & $\begin{array}{l}\text { İlm-i kelâm } \\
\text { Şevketî } \\
\text { Efendi }\end{array}$ & $\begin{array}{l}\text { Edebiyyât-1 } \\
\text { Fârisiyye } \\
\text { Hüseyin Dâniş } \\
\text { Bey }\end{array}$ & $\begin{array}{l}\text { Türk tarihi } \\
\text { Yusuf Akçura } \\
\text { Bey }\end{array}$ & $\begin{array}{l}\text { Terbiye-i } \\
\text { bedeniyye } \\
\text { Selim Sırrı Bey }\end{array}$ \\
\hline & Pazartesi & $\begin{array}{l}\text { Hadîs-i şerif } \\
\text { Şükrü } \\
\text { Efendi }\end{array}$ & $\begin{array}{l}\text { Coğrafya-i } \\
\text { Osmânî ve } \\
\text { İslâmî } \\
\text { Ali Tevfik Bey }\end{array}$ & $\begin{array}{l}\text { Hesap } \\
\text { Dâvud Paşa }\end{array}$ & $\begin{array}{l}\text { İlm-i fıkıh } \\
\text { Sâdık Efendi }\end{array}$ \\
\hline & Salı & $\begin{array}{l}\text { İlm-i kelâm } \\
\text { Şevketî } \\
\text { Efendi }\end{array}$ & $\begin{array}{l}\text { Coğrafya-i } \\
\text { umûmî } \\
\text { Ali Tevfik Bey }\end{array}$ & $\begin{array}{l}\text { Târîh-i umûmî } \\
\text { Ali Tevfik Bey }\end{array}$ & $\begin{array}{l}\text { Edebiyyât-1 } \\
\text { Arabiyye } \\
\text { Mârûf Rusâfî } \\
\text { Efendi }\end{array}$ \\
\hline & Çarşamba & $\begin{array}{l}\text { Hesap } \\
\text { Dâvud Paşa }\end{array}$ & $\begin{array}{l}\text { Edebiyyât-1 } \\
\text { Osmâniyye } \\
\text { Akif Bey }\end{array}$ & $\begin{array}{l}\text { Hendese } \\
\text { Dâvud Paşa }\end{array}$ & $\begin{array}{l}\text { İlm-i fıkıh } \\
\text { Sâdık Efendi }\end{array}$ \\
\hline & Perşembe & $\begin{array}{l}\text { Hitabet ve } \\
\text { mev'iza } \\
\text { Midhat } \\
\text { Cemal Bey }\end{array}$ & - & $\begin{array}{l}\text { Siyer-i nebî ve } \\
\text { târîh-i İ̀lâm } \\
\text { Mustafa Âsım } \\
\text { Efendi }\end{array}$ & $\begin{array}{l}\text { Terbiye-i } \\
\text { bedeniyye } \\
\text { Selim Sırrı Bey }\end{array}$ \\
\hline
\end{tabular}

31 Cerîde-i İlmiyye, 9, s. 573-76. 


\begin{tabular}{|c|c|c|c|c|c|}
\hline & $\begin{array}{l}\text { Günler/ } \\
\text { Dersler }\end{array}$ & 1. Ders & 2. Ders & 3. Ders & 4. Ders \\
\hline \multirow{6}{*}{$\begin{array}{c}2 . \\
\text { Sinif }\end{array}$} & Cumartesi & $\begin{array}{l}\text { Mâlûmât-1 } \\
\text { hukūkıyye } \\
\text { Mehmed } \\
\text { Celâleddin } \\
\text { Bey }\end{array}$ & $\begin{array}{l}\text { Tefsîr-i şerif } \\
\text { Mustafa Efendi }\end{array}$ & $\begin{array}{l}\text { Târîh-i Osmânî } \\
\text { Atâ Bey }\end{array}$ & $\begin{array}{l}\text { Usûl-i fikıh } \\
\text { Hamdi Efendi }\end{array}$ \\
\hline & Pazar & $\begin{array}{l}\text { Edebiyyât-1 } \\
\text { Fârisiyye } \\
\text { Hüseyin } \\
\text { Dâniş Bey }\end{array}$ & $\begin{array}{l}\text { Hadîs-i şerif } \\
\text { Şükrü Efendi }\end{array}$ & $\begin{array}{l}\text { İlm-i kelâm } \\
\text { Malkaralı Hil- } \\
\text { mi Efendi }\end{array}$ & $\begin{array}{l}\text { Terbiye-i } \\
\text { bedeniyye } \\
\text { Selim Sirrı Bey }\end{array}$ \\
\hline & Pazartesi & $\begin{array}{l}\text { İlm-i fikıh } \\
\text { İsâmüddin } \\
\text { Efendi }\end{array}$ & $\begin{array}{l}\text { Cebir } \\
\text { Dâvud Paşa }\end{array}$ & $\begin{array}{l}\text { Edebiyyât-1 } \\
\text { Osmâniyye } \\
\text { Atâ Bey }\end{array}$ & $\begin{array}{l}\text { Târîh-i umûmî } \\
\text { Abdurrahman } \\
\text { Şeref Bey }\end{array}$ \\
\hline & Salı & $\begin{array}{l}\text { İlm-i fikıh } \\
\text { İsâmüddin } \\
\text { Efendi }\end{array}$ & $\begin{array}{l}\text { Hadîs-i şerif } \\
\text { Şükrü Efendi }\end{array}$ & $\begin{array}{l}\text { İlm-i kelâm } \\
\text { Malkaralı Hil- } \\
\text { mi Efendi }\end{array}$ & - \\
\hline & Çarşamba & $\begin{array}{l}\text { Hikmet-i } \\
\text { tabîiye } \\
\text { Râif Yesârî } \\
\text { Bey }\end{array}$ & $\begin{array}{l}\text { Siyer-i nebî ve } \\
\text { târîh-i İslâm } \\
\text { Mustafa Âsım } \\
\text { Efendi }\end{array}$ & $\begin{array}{l}\text { Usûl-i fikıh } \\
\text { Hamdi Efendi }\end{array}$ & $\begin{array}{l}\text { Tefsîr-i şerif } \\
\text { Mustafa Efendi }\end{array}$ \\
\hline & Perşembe & $\begin{array}{l}\text { Târîh-i } \\
\text { umûmî } \\
\text { Abdurrah- } \\
\text { man Şeref } \\
\text { Bey }\end{array}$ & $\begin{array}{l}\text { Hitabet ve } \\
\text { meviza } \\
\text { Midhat Cemal } \\
\text { Bey }\end{array}$ & $\begin{array}{l}\text { Edebiyyât-1 } \\
\text { Arabiyye } \\
\text { Mârûf Rusâfî } \\
\text { Efendi }\end{array}$ & $\begin{array}{l}\text { Terbiye-i } \\
\text { bedeniyye } \\
\text { Selim Sirrı Bey }\end{array}$ \\
\hline \multirow{6}{*}{$\begin{array}{c}3 . \\
\text { Sinif }\end{array}$} & Cumartesi & $\begin{array}{l}\text { Târîh-i } \\
\text { edyân } \\
\text { Mahmud } \\
\text { Esad Efendi }\end{array}$ & $\begin{array}{l}\text { Tefsîr-i şerif } \\
\text { Mûsâ Kâzım } \\
\text { Efendi }\end{array}$ & $\begin{array}{l}\text { Hey'et } \\
\text { Fatin Efendi }\end{array}$ & $\begin{array}{l}\text { Hitabet ve } \\
\text { mev'iza } \\
\text { Sâlih et-Tûnisî } \\
\text { Efendi }\end{array}$ \\
\hline & Pazar & $\begin{array}{l}\text { Hıfzıssıhha } \\
\text { Mustafa } \\
\text { Münif Paşa }\end{array}$ & $\begin{array}{l}\text { İlm-i kelâm } \\
\text { Abdüllatif } \\
\text { Efendi }\end{array}$ & $\begin{array}{l}\text { Hadîs-i şerif } \\
\text { Mekkî U'dûr } \\
\text { Efendi }\end{array}$ & $\begin{array}{l}\text { Terbiye-i } \\
\text { bedeniyye } \\
\text { Selim Sirrı Bey }\end{array}$ \\
\hline & Pazartesi & $\begin{array}{l}\text { Kimya } \\
\text { Osman Nûri } \\
\text { Bey }\end{array}$ & $\begin{array}{l}\text { Tefsîr-i şerif } \\
\text { Mûsâ Kâzım } \\
\text { Efendi }\end{array}$ & $\begin{array}{l}\text { Usûl-i fikıh } \\
\text { Hamdi Efendi }\end{array}$ & $\begin{array}{l}\text { Edebiyyât-1 } \\
\text { Osmâniyye } \\
\text { Ata Bey }\end{array}$ \\
\hline & Salı & $\begin{array}{l}\text { Edebiyyât-1 } \\
\text { Arabiyye } \\
\text { Fehmi Efendi }\end{array}$ & $\begin{array}{l}\text { Felsefe } \\
\text { Mehmet Ali } \\
\text { Ayni Bey }\end{array}$ & $\begin{array}{l}\text { Usûl-i fikıh } \\
\text { Hamdi Efendi }\end{array}$ & $\begin{array}{l}\text { İlm-i fikıh } \\
\text { İsâmüddin } \\
\text { Efendi }\end{array}$ \\
\hline & Çarşamba & $\begin{array}{l}\text { İlm-i fikıh } \\
\text { İsâmüddin } \\
\text { Efendi }\end{array}$ & $\begin{array}{l}\text { Hikmet-i } \\
\text { tabîiye } \\
\text { Râif Yesârî Bey }\end{array}$ & $\begin{array}{l}\text { Mevâlîd-i } \\
\text { selâse } \\
\text { Müştak Bey }\end{array}$ & $\begin{array}{l}\text { Mevâlîd-i } \\
\text { selâse } \\
\text { Müştak Bey }\end{array}$ \\
\hline & Perşembe & $\begin{array}{l}\text { İlm-i kelâm } \\
\text { Abdüllatif } \\
\text { Efendi }\end{array}$ & $\begin{array}{l}\text { Hadîs-i şerif } \\
\text { Mekkî U'dûr } \\
\text { Efendi }\end{array}$ & - & $\begin{array}{l}\text { Terbiye-i } \\
\text { bedeniyye } \\
\text { Selim Sirrı Bey }\end{array}$ \\
\hline
\end{tabular}




\begin{tabular}{|c|c|c|c|c|c|}
\hline & $\begin{array}{l}\text { Günler/ } \\
\text { Dersler }\end{array}$ & 1. Ders & 2. Ders & 3. Ders & 4. Ders \\
\hline \multirow{6}{*}{$\begin{array}{c}4 . \\
\text { Sinif }\end{array}$} & Cumartesi & $\begin{array}{l}\text { İlm-i ferâiz } \\
\text { ve intikal } \\
\text { kanunu } \\
\text { Şevket Efen- } \\
\text { di }\end{array}$ & $\begin{array}{l}\text { İlm-i iktisat ve } \\
\text { malî } \\
\text { Niyazi Âsım } \\
\text { Bey }\end{array}$ & - & $\begin{array}{l}\text { Hadîs-i şerif } \\
\text { Mekkî U'dûr } \\
\text { Efendi }\end{array}$ \\
\hline & Pazar & $\begin{array}{l}\text { İlm-i kelâm } \\
\text { Abdüllatif } \\
\text { Efendi }\end{array}$ & $\begin{array}{l}\text { İlm-i fikıh } \\
\text { Tavaslı Hasan } \\
\text { Efendi }\end{array}$ & $\begin{array}{l}\text { Hitabet ve } \\
\text { mev'iza } \\
\text { Sâlih et-Tûnisî } \\
\text { Efendi }\end{array}$ & $\begin{array}{l}\text { Terbiye-i } \\
\text { bedeniyye } \\
\text { Selim Sırrı Bey }\end{array}$ \\
\hline & Pazartesi & $\begin{array}{l}\text { Tefsîr-i şerif } \\
\text { Ahmed } \\
\text { Mâhir Efendi }\end{array}$ & $\begin{array}{l}\text { Târîh-i mede- } \\
\text { niyet } \\
\text { Ahmed Refik } \\
\text { Bey }\end{array}$ & $\begin{array}{l}\text { İlm-i içtimâ ve } \\
\text { terbiye } \\
\text { Diyarbakırlı } \\
\text { Ziya Bey }\end{array}$ & $\begin{array}{l}\text { Usûl-i fikıh } \\
\text { Hamdi Efendi }\end{array}$ \\
\hline & Salı & $\begin{array}{l}\text { Felsefe } \\
\text { Mehmet Ali } \\
\text { Ayni Bey }\end{array}$ & $\begin{array}{l}\text { İlm-i fikıh } \\
\text { Tavaslı Hasan } \\
\text { Efendi }\end{array}$ & $\begin{array}{l}\text { Kimya } \\
\text { Osman Nûri } \\
\text { Bey }\end{array}$ & - \\
\hline & Çarşamba & $\begin{array}{l}\text { İlm-i kelâm } \\
\text { Abdüllatif } \\
\text { Efendi }\end{array}$ & $\begin{array}{l}\text { İlm-i iktisat ve } \\
\text { malî } \\
\text { Niyazi Âsım } \\
\text { Bey }\end{array}$ & $\begin{array}{l}\text { Hikmet-i } \\
\text { tabîiyye } \\
\text { Râif Yesârî Bey }\end{array}$ & $\begin{array}{l}\text { Usûl-i fikıh } \\
\text { Hamdi Efendi }\end{array}$ \\
\hline & Perşembe & $\begin{array}{l}\text { Tefsîr-i şerif } \\
\text { Ahmed } \\
\text { Mâhir Efendi }\end{array}$ & $\begin{array}{l}\text { Târîh-i mede- } \\
\text { niyet } \\
\text { Ahmed Refik } \\
\text { Bey }\end{array}$ & $\begin{array}{l}\text { Hadîs-i şerif } \\
\text { Mekkî U'dûr } \\
\text { Efendi }\end{array}$ & $\begin{array}{l}\text { Terbiye-i } \\
\text { bedeniyye } \\
\text { Selim Sırrı Bey }\end{array}$ \\
\hline
\end{tabular}

Medresenin nizamnâmesinde imtihanlar, talebenin medreseye devamı ve disiplini ile maddî imkânların sağlanması gibi hususlara da temas edilmiştir. Buna göre, medreseye her yıl yapılacak müsabaka imtihanı ile kırk talebe kabul edilecektir. Kabul şartları arasında, talebelerin yirmi-otuz yaşları arasında bulunmaları ve sabıkasız olmaları gibi diğer medreselere giriş için de aranan şartların yanı sıra kekemelik, düzgün ve akıcı ifadeye sahip olmak, mezuniyetten sonra dört yıllık zorunlu hizmeti kabul etmek şartları da ileri sürülmüştür. Her biri bir önceki için baraj olan ilk ikisi yazıll, sonrakileri ise sözlü dört aşamada gerçekleştirilecek imtihanların ilkinde talebelerden, Arapça bir metni harekeleyip Türkçeye tercüme etmeleri, ikincisinde ise Türkçe’ye hâkimiyetlerinin ölçülmesi amacıyla bir mektup yazdırılarak, dil bilgisi yönünden tahlil etmeleri istenecektir. Sözlü imtihanlar ise önce din ilimlerinden, ardından hesap, coğrafya ve tarih gibi derslerden yapılacaktır. İmtihanlardan her biri yirmi tam puan üzerinden değerlendirilen imtihanlardan en az on puan alanlar başarılı sayılacak, başarılı talebe sayısının kontenjanın üzerinde olması halinde ise sıralama yapılarak kontenjan sayısı 
kadar, buna ek olarak diğer İslâm ülkelerinden de on talebe kabul edilecektir. Yabancı uyruklu talebeler, dersleri takip edebilecek derecede Türkçe bilmeleri halinde, diğer imtihanlarda başarılı olmaları şartıyla bu dersin imtihanından muaf tutulacaklardır. ${ }^{32}$

Talebelerin öğrenimleri sırasındaki imtihanlarda ise diğer medreselerde rastlanmayan farklı bir usul getirilerek yıl sonunda yapılan sinıf geçme imtihanları yanında, genel başarının tespitinde dikkate alınmak üzere, aralık ayının ilk haftasında hususi imtihanlar adıyla günümüzde de uygulanan ara imtihanlarının yapılması kararlaştırılmıştır. İki kişilik bir komisyon nezaretinde yapılacaktır. Talebelerin başarılı sayılabilmeleri için, tam notun on olarak belirlendiği haziran ayındaki sınıf geçme imtihanlarında, o yıl gördükleri bütün derslerden alınabilecek tam notların toplamının üçte ikisini almaları gerekmektedir. Bu notu aldığı halde sadece bir dersten beşten aşağı not alanlar bütünlemeye kalacak, diğerleri ise başarısız sayıldığından aynı sınıfı tekrarlamaları gerekecektir. Meselâ on altı dersten imtihana giren bir talebenin, bu derslerin tam notu olan 160'ın üçte ikisi 107 puanı, hiçbir dersten beşten aşağı notu olmamak şartıyla alması gerekmektedir.

15 Eylül-15 Mayıs tarihleri arasında dokuz ay devam edecek öğretim süresi içinde günde üç veya dört ders yapılacak medresede cuma, haftalık tatil günü olarak belirlenmiştir. Yine nizamnâmede, talebelerin derslerine çalışmamaları, siyasetle uğraşmaları, idarî işlere müdahaleleri ve idarenin getirdiği kurallara uymamaları gibi davranışları disiplinsizlik olarak kabul edilerek bu tür davranışlarda bulunanların ihtar, tahsisatın kesilmesi ve kayıt silinmesi şeklinde cezalandırılmaları öngörülmektedir. ${ }^{33}$

Diğer medreselerle karşılaştırıldığında Medresetü'l-vâizîn talebelerinin maddî ihtiyaçlarının giderilmesine daha fazla önem verildiği görülmektedir. Bu dönemde, medrese talebelerinin yemeklerini imaretlerden karşılama hakları bulunmaktadır. 1910 yılında hazırlanan nizamnâme ile bütün medrese talebelerine imaretlerden yemek verilmesi yerine, bunun bedeli olarak ayda 70 kuruş ödenmesi kararlaştırılmış; ancak bu uygulamadan 1914 y1lında vazgeçilerek Dârüll-hilâfeti'l-aliyye Medresesi talebesine iâş̧e ve elbise yardımının yapılmasına karar verilmiştir. Genel medreselerdeki bu uygulamanın dışında Medresetü’l-vâizîn talebelerine ayrıca ayda 150 kuruş ödenmesi karara bağlanmıştır. ${ }^{34}$

32 “Medresetü’l-vâizîn Nizamnâmesi”, s. 212-13 (md. 2, 9-10); Medresetü'l-vâizîn Nizamnâme ve Tâlimatnâmesi, s. 8-9 (md. 11-13, 16).

33 Medresetü'l-vâizîn Nizamnâme ve Tâlimatnâmesi, s. 12 (md. 44-46).

34 “Talebe-i Ulûm Tahsisatına Dair Nizamnâme”, s. 2-3; “Medresetü’l-vâizîn Nizamnâmesi”, s. 212 (md. 44-46). 
Medreseden mezun olanlar mezuniyet derecelerine göre büyük camilerin vâizlikleri ile askerî birliklerdeki imamlık ve vâizlik görevlerine imtihansız olarak atanabileceklerdir. ${ }^{35}$ Mezunlar için dört yıllık bir zorunlu hizmet şartı bulunduğundan, görev almak istemeyenler tahsil masraflarını ödemekle yükümlü tutulmaktadır. ${ }^{36} 1924$ yılında açılan Dârülfünun İlâhiyat Fakültesỉne kayıt yaptıranlar arasında Medresetü’l-vâizîn mezunu on beş talebe bulunmaktadır.

Evkaf Nezâreti Müessesât-1 İlmiyye Müdüriyeti’ne bağlı olarak kurulan Medresetül-vâizîn ile Medresetü'l-eimme ve'l-hutabâ birleștirilerek 1919 y1lında Medresetü'l-irşâd adıyla meşihata bağlanmıştır. ${ }^{37}$

Bu konuyu bitirirken Medresetü'l-vâizîn'in kurulması fikrinin nasıl ortaya çıtığı hususu üzerinde durmak istiyoruz. Vâizliğin önemi ve nitelikli vâizlerin yetiştirilmesinin gerekliliği konusu, Muhammed Abduh tarafından II. Abdülhamid'e gönderilen ve bu dönemde gerçekleștirilen eğitimin düzenlenmesi çalışmalarını destekleyerek birtakım öneriler içeren mektuplarda da dile getirilmektedir. ${ }^{38}$ Abduh, hem varlıklı insanların yeni mekteplerin inşa edilmesine katkılarının sağlanması ve halkın çocuklarını mekteplere göndermeleri hem de eksik olan dinî bilgilerini tamamlamaları ve devlete olan bağlılıklarını sağlamak konusunda vâizlerin olumlu yöndeki katkılarının sağlanması gerektiğinden bahsederek, dini anlatacak ve avamı irşat edecek iyi yetişmiş vâizlere ihtiyaç olduğundan söz etmektedir. Diğer taraftan Reşîd

35 "Medresetü'l-vâizîn Nizamnâmesi”, s. 213-214 (md. 11); "Alay ve Tabur İmamlarının

Vezâif-i Tedrisiyeleri Hakkında Nizamnâme”, s. 332-33 (md. 6).

36 Medresetül-vâizîn Nizamnâme ve Tâlimatnâmesi, s. 13 (md. 48).

37 BOA, MV, 250/72; Cerîde-i İlmiyye, 51, s. 1239.

38 Arapça olarak kaleme alınan bu mektuplar için bk. BOA, Y. EE, 38/14, 15; 38/15 numarada kayıtlı ve devrin şeyhülislâmına hitaben yazılan mektup Türkçe'ye çevrilerek yayımlanmıştır. Bk. Akgündüz, "Muhammed Abduh’un Gözüyle Osmanlı Devleti ve Eğitim Sistemi”, s. 34-41. 38/14 numarada kayıtlı, ilk mektubun dikkate alınması için padişaha hitaben yazılan diğer mektup ve çevirisi ise aynı kayıtta yer almaktadır. Üzerinde tarih bulunmayan her iki mektup 6 Rebîulâhir 1327 (27 Nisan 1909) tarihi ile kaydedilmiştir; ancak Muhammed Abduh'un 11 Temmuz 1905 tarihinde vefat ettiği göz önüne alındığında, bu tarihin, mektupların yazıldığı tarih olması mümkün değildir. Bu durum, mektupların II. Abdülhamid döneminde yazılmış olmasına rağmen, daha sonra kayda alındığını göstermektedir. İlginçtir ki 27 Nisan 1909, II. Abdülhamid'in tahttan indirildiği tarihtir. Mektubun tarihlendirilmesinde, Abduh'un mektubunda sözünü ettiği ve mektubu yazmasına sebep olan eğitim düzenlemesi çalışmalarından hareket edilebilir; ancak bu dönemde çeşitli tarihlerde eğitim düzenlemeleri yapıldığına bakılırsa bu yol da kesin sonuç vermeyebilir. Bununla birlikte, Muhammed Abduh'un mektubunda, mektubu yazmasına sebep olan çalışmanın şeyhülislâm başkanlığında bir heyet tarafından gerçekleştirileceğinden bahsetmesine bakılarak, mektubun 1887 yılında yazıldığ 1 ileri sürülebilir. Nitekim bu tarihte Şeyhülislâm Ahmed Esat Efendi başkanlığında böyle bir çalışma yapılmıştır. Bk. BOA, Y. MTV, 25/52. 
Rızẩın orta öğretim yapılan kısmından vâizlerin yetişeceği, yatılı ve Arapça öğretimin yapılacağı büyük bir medresenin kurulmasını tasarladığından; hatta vâiz yetiştirmek üzere özel bir medresenin kurulmasına ilk defa teșebbüs ettiğinden söz edilmektedir. ${ }^{39}$ Reşîd Rızâ 1910 yılındaki İstanbul ziyareti ile ilgili yazdığ yazıda, eğitimin ve medreselerin ıslahı ile vaaz ve irşat için bir kurumun oluşturulması konusunda meşihat görevlileri ile temasından söz etmektedir. ${ }^{40}$

Bütün bunlarla birlikte unutmamak gerekir ki Osmanlı eğitim sisteminde yenilik hareketleri Tanzimat’tan itibaren her alanda olduğu gibi din eğitimi konusunda da devam etmektedir. II. Abdülhamid döneminde olduğu gibi II. Meşrutiyet yıllarında da medreselerin ıslahı ve din eğitimi konusunda birçok talep ve teklif olmuş, bu konuda birçok çalışma yapılmıştır. Yine bu talep ve tekliflerin bir sonucu olarak ilk medrese ıslahı 1910 yılında gerçekleştirilmiştir. Bütün bunlar, söz konusu çalışmaların Osmanlı ulemâ, aydın ve devlet adamlarının planlı ve amaçlı çalışmalarının bir ürünü olduğunu, bunun için de gerekli birikimin mevcut olduğunu göstermektedir. Buna, dönemin siyasî durumu ve İstanbul'da Arapça eğitim yapılan bir kurumun açılmasının imkânı ve değeri de katıldığında, bu kurumun açılmasında sözü edilen kimselerin fikirlerinin tesiri olduğunu zikretmenin anlamsız olduğu görülecektir.

Sonuç olarak II. Meşrutiyet döneminde vâiz yetiştirmek üzere meslekî ihtisas medresesi olarak Medresetü'l-vâizîn’in kurulması ve yapılan diğer çalışmalar, ehliyetli din görevlilerinin yetiştirilmesine verilen ehemmiyeti göstermektedir. 1914 yllında cami ve mescitlerde görevlendirilecek vâizler hakkında hazırlanan nizamnâme, vilâyetlere ve müstakil livâ mutasarrıflıklarına gönderilmiştir. ${ }^{41}$ Diğer taraftan, Tanzimat'tan itibaren açılan mekteplerin idaresi ve eğitim yapılanması, medreselerde de mekteplerle uyumlu benzer çalışmaların yapılmasını teşvik etmiştir. Böylece bir yandan medreselerdeki eğitim kalitesinin arttırılması için çaba sarfedilirken diğer taraftan da din hizmetlerinde ihtiyaç duyulan personelin ayrı kurumlarda yetiştirilmesine girişilmiştir. II. Meşrûtiyet döneminde medreselerin ıslahına gayret edilmesi ve halka dinî konularda rehberlik edecek vâizlerin ve imamların yetiştirilmesi için meslek medreselerinin açılması bu girişimlerin sonucu olarak

39 Ergün, “II. Meşrutiyet Döneminde Medreselerin Durumu”, s. 88-89; Sarıkaya, Medreseler ve Modernleşme, s. 177-79; Akman, Osmanlı Devletinin Son Döneminde Bir Üst Kurul, s. 57; Akgündüz, Osmanl Döneminde Vâizlik, s. 14.

4o Reşid Rıza, “Meşrutiyet İstanbul'una Seyahat ve Dâru'l-İlm ve'l-İrşâd Projesi”, s. 163-87. 41 "Cevâmi've Mesâcid-i Şerîfede Vaaz ve Nasihat Edecek Ulema Hakkında Nizamnâme", s. 375; Cerîde-i İlmiyye, 1, s. 18-19. 
değerlendirilmelidir. Bu dönemde medrese mensuplarının, toplumun çeşitli alanlarda ihtiyaç duyduğu elemanların yetiştirilmesi fikrinden tamamen kurtularak aslî vazifeleri olan din eğitimi ve öğretimi konusuna eğilmeleri olumlu bir gelişmedir; ancak yapılan çalışmaların yeterli olduğunu, buradan yetişen din görevlileri ile ihtiyacın karşılanacağını söyleyebilmek mümkün değildir. Zira yukarıda her yıl kırk talebenin kabul edileceğini belirttiğimiz Medresetü'l-vâizîn'den mezun talebelerin tamamı görev alsa dahi bu sayının ülkenin vâiz ihtiyacına cevap veremeyeceği açıktır.

\section{B. Medresetü'l-eimme ve'l-hutabâ}

Osmanlılar döneminde imamların görevi yalnızca namaz kıldırmak, halkın dinî ihtiyaçlarını karşılamalarında yardımcı olmakla sınırlandırılmamış, aynı zamanda bugünkü mahalle muhtarlarının görevlerinin yanı sıra, muhitlerindeki evlenme-boşanma, nüfus ve tapu kayıtlarını tutmak gibi vazifeleri de kapsamıştır. İmamlara, görevde bulundukları süre içerisinde vergi muafiyeti de sağlanmıştır. ${ }^{42}$ II. Abdülhamid döneminde sancak merkezlerinde hem muallimlik hem de imamlık görevlerini aynı anda yürütecek muallimler yetiştirecek mektepler açılması yanı sıra köy imamlarının kaza merkezlerinde kurslara tâbi tutularak muallim olarak görevlendirilmesi fikri ortaya atılmış; ancak gerçekleştirilememiştir. ${ }^{43}$

1913 yllında imam, hatip ve müezzin yetiştirmek üzere açllan Medresetü'leimme ve'l-hutabâ, Hutabâ ve Eimme ile Müezzinîn şubelerinden müteşekkildir. Müezzinîn Şubesi daha sonraki yıllarda Ezan ve İlâhi Şubesi adını almıştır. ${ }^{44}$ Medresenin kuruluşu ve eğitim öğretim durumu hakkında ayrıntılı bilgiye sahip değiliz; ancak elimizdeki mevcut bilgilere dayanarak, bu kurum hakkında yine de bir fikir edinmek mümkündür. Medresenin farklı şubeleri için hazırlanan programlarda şu derslere yer verilmiştir:

İmam ve Hatipler Kısmı’nın 1917 (1333) tarihindeki programı: Kur'ân-1 Kerim, ahkâm-1 ibâdât, ahkâm-1 nikâh ve talâk, ilm-i kelâm, hutbe nazariyat1, hutbe tatbikatı, Türkçe hutbe, mâlûmât-1 kānûniyye. Müezzinîn Şubesỉnin aynı tarihteki programında ise Kur'ân-1 Kerim, ahkâm-1 ibâdât, ezan-ilâhi-na't-mevlit nazariyatı, ezan-ilâhi-na't-mevlit tatbikatı dersleri

42 Bk. Kazıc1 - Şeker, İslam-Türk Medeniyeti, s. 164-69; Beydilli, Osmanlılar Döneminde Imamlar, s. 5-20.

43 BOA, ŞD, 207/36; Kodaman, Abdülhamit Devri Eğitim Sistemi, s. 241.

44İstanbul Müftülüğü Şer'iyye Sicilleri Arşivi, Medresetü’l-hutabâ Talebesinin Künye

Defteri, nr. 2339; Cerîde-i İlmiyye, 48, s. 1515. 
bulunmaktadır. ${ }^{45}$ Bu programın, medresenin 1919 yılında Medresetü'l-irşâd'a katılmasına kadar devam ettiği, bu tarihte yapılan genel imtihanlarda da aynı derslere yer verilmesinden anlaşılmaktadır. ${ }^{46}$

Medresenin Hutabâ ve Eimme Şubesỉnden Ağustos 1333 (Ağustos 1917) tarihinde yirmi bir, Eylül 1334 (Eylül 1918) tarihinde iki kişi mezun olmuştur. Ezan ve İlâhi Şubesỉnden ise 1917 ve 1918 ylllarında sekiz, 1919 yılında ise dokuz kişi mezun olmuştur. ${ }^{47} 1919$ yılında Hutabâ ve Eimme Şubesi birinci sınıfındaki altı talebeden üçünün, Ezan ve İlâhi Şubesỉndeki yedi talebeden altısının başarılı olarak bir üst sınıfa geçtikleri görülmektedir. Bu bilgilerden medresenin her iki şubesinde sadece on üç talebenin bulunduğu anlaşılmaktadır. ${ }^{48}$

1913 yllında hazırlanan imam, hatip ve müezzin gibi din görevlilerinin atanmalarında takip edilecek usulün belirtildiği Tevcîh-i Cihât Nizamnâmesi'nde imamlık ve hatiplik görevine atanacakların Halebî adlı kitaptan bir ibareyi harekelendirip tercüme ettirilmesi, ibâdât, nikâh, kelâm ve tecvitten çeşitli sorular sorulması ve Kur'an'dan bir parçanın okutturulması şeklinde imtihan edilmeleri kararlaştırılmıştır. Müezzin adaylarına ise müezzinliğe dair fikhî sorular sorulacak, ayrıca tecvit kurallarına göre Kur'an'dan bir parça okutulacaktır. ${ }^{49} \mathrm{Bu}$ imtihanlarda aranan şartlara bakılarak, medresenin bir kurs niteliğini taşıdığ ileri sürülmektedir. ${ }^{50}$ Ancak imtihanlarda aranılan şartlarla program karşılaştıılddığında her ikisi arasında tutarlılığın olduğu, imtihanların yapılacağı ibâdât, nikâh, kelâm, tecvit ve Kur'an derslerinin programda mevcut oldukları görülmektedir. Ancak Halebîden, Arapça bir metnin harekelenme ve tercümesi istendiği halde programda Arapça ile ilgili bir ders bulunmamaktadır ki bu durum da medreseye, az çok Arapça bilenlerin kabul edildiği düşünülerek açıklanabilir.

Sonuç olarak, hakkında fazla bir bilgiye sahip olmadığımız ve beklenen ilgiyi görmediği anlaşılan bu kurum, 1919 yılında Medresetü’l-vâizîn ile birlikte Medresetü’l-irşâd adıyla birleștirilmiştir.

45 İstanbul Müftülüğü Şer iyye Sicilleri Arşivi, Medresetü’l-hutabâ Talebesinin Künye

Defteri, nr. 2339.

46 Cerîde-i İlmiyye, 48, s. 1515-16.

47 İstanbul Müftülüğü Şer 'iyye Sicilleri Arşivi, Medresetü’l-hutabâ Talebesinin Künye

Defteri, nr. 2339.

48 Cerîde-i İlmiyye, 48, s. 1515-16.

49 "Tevcîh-i Cihât Nizamnâmesi”, s. 613 (md. 33-34).

50 Bk. Yazıcı, "Osmanlıların Son Döneminde Din Görevlisi Yetiştirme Çabaları Üzerine

Bazı Gözlemler”, s. 115. 


\section{Medresetü'l-irşâd}

II. Meşrutiyet dönemindeki medreselerin 1slahı çalışmaları yönetim, program ve öğretim süresi gibi hususlarda medreselerin geleneksel yap1sından farklı, nitelikli din görevlilerinin yetiştirilmesini amaçlayan yeni bir teşkilâtın kurulması çabasıdır. Söz konusu bu yenilik, atılan adımların zaman içerisinde tekrar geçirilmesini ve birtakım değişikliklerin yapılmasını gerektirmiştir. Medresetü'l-irşâad böyle bir gelişmenin sonucu olarak daha önce kurulmuş olan Medresetü'l-vâizîn ile Medresetü'l-eimme ve'l-hutabẩnın birleştirilmesiyle idaresi meşihata bağlı olarak açllan yüksek dereceli bir medresedir. $^{51}$

Yeni oluşturulan bir kurumun kuruluş ve işleyiş esaslarına ait doğru bilginin elde edileceği en önemli kaynaklardan biri de nizamnâmelerdir. Yaptığımız araştırma sonunda Medresetü'l-irşâd'ın kurulması ve işleyiş esaslarını içeren bir nizamnâmenin varlığını tespit ettik. ${ }^{52} 1919$ yllında medresenin kurulmasından hemen sonra hazırlanmaya başlanan bu nizamnâme, medresenin varlığına ihtiyaç olup olmadığı ve buna bağlı olarak kaynak aktarımı konularında meşihat ve evkaf arasındaki anlaşmazlık sebebiyle hiçbir zaman uygulamaya konulamamıștır. Ancak buna rağmen medrese, meşihata bağlı bir kurum olan Dârüll-hikmeti'l-İslâmiyye’nin idaresinde faaliyetlerini sürdürmüştür. Bu çerçevede Dârü’l-hikmeti'l-İslâmiyye’nin kararı ile medresenin müdürlügüne 14 Ağustos 1919 tarihinde Yenişehirli Ahmed Şâkir Efendi $\operatorname{atanmıştır.~}^{53}$

Nizamnâmesi hazırlanamamış olsa da Medresetü'l-irşâd, kurulduğu tarihten itibaren taslak nizamnâmede sözü edilen esaslardan farklı biçimde faaliyetini sürdürmüştür. Bu sebeple kurumla ilgili olarak ilki nizamnâme çerçevesinde tasarlanan ancak uygulanamayan, diğeri ise fiilen gerçekleştirilen iki farklı yapı ile karşılaşılmaktadır. Her iki yapıyı karşılaştırarak benzer ve farklı yönlerini sebepleri ile açıklamak uygun olacaktır.

Nizamnâme 1919 yılında meşihat tarafından hazırlanarak incelenmek üzere önce Şûrâ-yı Devlet'e ardından da Evkaf Nezâreti’ne gönderilmiştir. ${ }^{54}$ Cerîde-i İlmiyye'de medresenin, Medresetüll-vâizîn ile Medresetü'l-eimme

511924 yılında İstanbul Dârülfünunu’na bağlı olarak açılan İlâhiyat Fakültesỉne iki Medresetü'l-irşâd mezununun kayıt yaptırmasının yanında, ileride yer verildiği gibi, medrese için hazırlanan taslak nizamnâmenin 6. maddesinde talebelerinin, diğer yüksek mektep talebelerinin haklarından yararlanacağının belirtilmesi, medresenin yüksek dereceli olduğunu göstermektedir.

52 BOA, BEO, nr. 4702/352593/9.

53 Akman, Osmanlı Devletinin Son Döneminde Bir Üst Kurul, s. 62-66.

54 BOA, ŞD, 2842/55. 
ve'l-hutabânın birleştirilerek kurulduğu bilgisi yer alırken ${ }^{55}$, nizamnâmenin ilk maddesinde Medresetü'l-irşâd'nn, Medresetü'l-vâizîn'in meşihatın ders vekâleti birimine 22 Cemâziyelâhir 1337 (25 Mart 1919) tarihli irade ile bağlanarak kurulduğu belirtilmektedir. Yine nizamnâmede öğretim süresi iki yıl olarak belirlenen medrese için herhangi bir bölümden söz edilmeyerek tek bir program verilmekte, mezunların istihdam alanları olarak vâizlik, imamlık, hatiplik ve ulûm-1 dîniyye muallimliği sayılmaktadır. Medresenin faaliyetiyle ilgili, ileride yer vereceğimiz elimizdeki bilgiler, nizamnâmedeki bu bilgilerle örtüşmemektedir. Tezat oluşturan bu durum, medresenin tasarlandığı yapı ile faaliyetini sürdüren yapısının farklı olduğu, tasarlanan yapıda herhangi bir bölüme yer verilmeyip tek bir programın uygulanacağı, eski yapının şimdilik devam ettiği biçiminde açılanabilir. Nizamnâmenin, uygulanmakta olan yapıdan farklı olmasının temel sebebi, taşıdığı eğitim amaçları açısından, getirdiği malî yüke değer, diğer medreselerden farklı ve özel bir amaca sahip olup olmadığı konusundaki tereddütlerdir. Kuruluşundan itibaren tartışılan bu konu, medresenin daha az malî külfet getirecek biçimde daha dar kapsamlı olarak planlanmasına sebep olmuştur.

Tablo 2: Medresetü’l-irşâd’ın Nizamnâmesinde Yer Verilen Ders Programı

\begin{tabular}{|l|c|c|}
\hline Dersler & 1. Sene & 2. Sene \\
\hline Tefsîr-i şerif & 3 & 3 \\
\hline Hadîs-i şerif & 3 & 3 \\
\hline İlm-i fikıh & 3 & 3 \\
\hline İlm-i kelâm & 2 & 2 \\
\hline İlm-i ahlâk & 3 & 3 \\
\hline Siyer ve târîh-i hulefâa & 2 & 2 \\
\hline Felsefe & 2 & 2 \\
\hline İlm-i içtimâ & 2 & - \\
\hline Târîh-i edyân & - & 2 \\
\hline Edebiyyât-1 Osmâniyye & 2 & 2 \\
\hline Edebiyyât-1 Fârisiyye & 1 & 1 \\
\hline Hitabet ve mev iza & $\begin{array}{c}|c| \\
\text { hainttada yekdigerini müteakiben iki } \\
\text { haattir. }\end{array}$ \\
\hline
\end{tabular}

55 Cerîde-i İlmiyye, 51, s. 1239-40. 
Meşihatın idaresine bağlanmakla birlikte masrafları Evkaf Nezâreti tarafindan karşılanacak olan medresenin talebeleri diğer yüksek dereceli mektep talebelerinin haklarından yararlanacak, askerlikte muaf tutulacak, ayrıca yiyecek ve giyecek ihtiyaçları kurum tarafından karşılanacaktır.

Nizamnâmesi hazırlanamamış olsa da Medresetü'l-irşâd, kurulduğu tarihten itibaren taslak nizamnâmede sözü edilen esaslardan farklı biçimde faaliyetini sürdürmüştür. Bu sebeple kurumun, ilki nizamnâme çerçevesinde tasarlanan ancak uygulanamayan, diğeri ise fiilen gerçekleştirilen iki farklı yapısı bulunmaktadır.

Medresetü'l-irşâd’’n ilk kurulduğu 1919 yılında Vâizîn ile Hutabâ ve Eimme şubelerinde okutulacak derslere yer verilmiştir. Buna göre öğretim süresi üç yıl olarak belirlenen Vâizîn Şubesỉnin 1919 yılına ait programında şu derslere yer verilmektedir: Tefsir, hadis, kelâm, fikıh, usûl-i fikıh, ferâiz, ahkâm-1 evkaf, mezâhib-i İslâmiyye ve turuk-1 âliyye, edyân, ilm-i ahlâk, siyer-i nebî ve târîh-i İslâm, edebiyyât-1 Türkiye ve inşâ, edebiyyât-1 Fârisî, târîh-i felsefe, ilm-i içtimâ, hıfzıssıhha, hitabet ve mev'iza. ${ }^{56}$ Şubeden 1920 yılında mezun olan talebelerin son sinıf imtihanlarının yapıldığ 1 dersler arasında kelâm, târîh-i edyân ve ilm-i içtimâ derslerinin olmaması, programdan çıkartıldıklarını göstermektedir. ${ }^{57}$ Yine şubenin 1920 yılında mezun vermesi, daha önce müstakil olan her iki medresenin programı ve idarî yapısında değişiklik yapıldığını, bunun dışında medresede halen okutulmakta olan talebelerin mevcut sınıflarında muhafaza edildiklerini ortaya koymaktadır. İki yıllık eğitim yapılan medresenin, kuruluşundan bir yıl sonra mezun vermesi mümkün değildir.

Vâizîn Şubesỉnin talebeleri için bazı maddî imkânların sağlandığı görülmektedir. Buna göre talebelere ayda 100 kuruş tahsisat sağlanacak, ayrıca mezunlar diğer yüksek dereceli mektep mezunlarının haklarından yararlanacaktır. Mezunlar, büyük camilerin vâizlikleri ve askerî birliklerin imamlıkları yanında vilâyet, livâ ve kasaba merkezlerindeki vâizliklere tayin edilecektir.

Öğretim süresi iki yıl olarak belirlenen Eimme ve Hutabâ Şubesi’ne gelince, daha önce müstakil bir kurum olan Medresetü'l-eimme ve'l-hutabâ içerisinde bir şube olan Müezzinîn ya da sonraki adıyla Ezan ve İlâhi Şubesi’ne yeni yapı içerisinde yer verilmemiştir. Mezunları imamlık, hatiplik ve müezzinlik görevlerine atanacak olan Eimme ve Hutabâ Şubesi için hazırlanan ilk programda yer alan tertîl-i Kur'ân-1 Kerim, fikıh, tevhit,

56 Cerîde-i İlmiyye, 51, s. 1239-40.

57 Cerîde-i İlmiyye, 62, s. 1995. 
mâlûmât-1 kānûniyye ve hitabet, derslerine 1920 yılında ilm-i vücûh ve k1raat, hadîs-i şerif, bazı suver-i şerife tefsiri, ahlâk, usûl-i inşâ ve mûsıki dersleri eklenmiştir. ${ }^{58}$ Daha sonra tekrar düzenlenen programda tefsir, hadis ve ahlâk dersleri kaldırılarak ezân-1 Muhammedî, tecvit ve mevlîd-i nebevî dersleri eklenmiştir ${ }^{59}$ (Tablo 3).

Tablo 3: Medresetü'l-irşâd’n Eimme ve'l-Hutabâ Şubesỉnin 29 Kânunusâni 1339 (29 Ocak 1923) Tarihine Ait Ders Programı

\begin{tabular}{|l|l|l|l|l|l|l|}
\hline & Cumartesi & Pazar & Pazartesi & Salı & Çarşamba & Perşembe \\
\hline 1. Ders & Hıfzıssıhha & Hitabet & Mûsiki & Hıfzıssıhha & $\begin{array}{l}\text { Mevlîd-i } \\
\text { nebevî }\end{array}$ & Hitabet \\
\hline 2. Ders & $\begin{array}{l}\text { Kur'ân-1 } \\
\text { Kerim }\end{array}$ & Tecvit & $\begin{array}{l}\text { Ezân-1 } \\
\text { Muhammedî }\end{array}$ & $\begin{array}{l}\text { Kur'ân-1 } \\
\text { Kerim }\end{array}$ & Mûsiki & Tevhit \\
\hline 3. Ders & Tecvit & Fıkıh & $\begin{array}{l}\text { Mevlîd-i } \\
\text { nebevî }\end{array}$ & Tecvit & $\begin{array}{l}\text { Mâlûmât-1 } \\
\text { kānûniyye }\end{array}$ & Fıkıh \\
\hline 4. Ders & İnşâa & $\begin{array}{l}\text { İlm-i } \\
\text { vücûh }\end{array}$ & İnşâa & $\begin{array}{l}\text { İlm-i } \\
\text { vücûh }\end{array}$ & $\begin{array}{l}\text { İlm-i } \\
\text { vücûh }\end{array}$ & $\begin{array}{l}\text { Mâlûmât-1 } \\
\text { kânûniyye }\end{array}$ \\
\hline
\end{tabular}

Medresetü'l-irşâd'ın kurulmasından yaklaşık olarak bir buçuk sene sonra evkaf bütçesinden karşılanan tahsisatı, diğer medreseler varken böyle bir medreseye ihtiyacın olmadığı ve getirdiği malî yük sebebiyle Haziran 1921 tarihinde kesilmiştir. ${ }^{60}$ Evkaf Nezâreti’nin konuyla ilgili olarak aynı yılın ekim ayında hazırladığı raporda, otuz talebeye karşılık kırk bir muallim ve altı idarî personelin görev yaptığ 1 medresede, talebenin iâşesi ve elektrik masrafı eklendiğinde kurumun maliyetinin çok yüksek olduğu belirtilerek vakıf gelirlerinin verimli olmayan alanlarda harcanmasının yanlış olacağ

58 Cerîde-i İlmiyye, 51, s. 1239; 62, s. 1996.

59 İstanbul Müftülüğü Şer iyye Sicilleri Arşivi, Eimme ve Hutabâ Şubesi Yoklama Defteri, sene 1335-13 (1919-24), nr. 2338. Bu defterde, yine aynı şubeye ait 11 Kânunusâni 1335 (11 Ocak 1919) ve 29 Kânunusâni 1339 (29 Ocak 1923) tarihli, Medresetü'l-irşâd'ın kurulmasından hemen sonrasına ait bir program daha bulunmaktadır. Ancak bu programın uygulanmadığını, sadece taslak olarak hazırlandığını tahmin ediyoruz; zira yer alan dersler ile medresenin Eimme ve Hutabâ Şubesi'nde okutulması kararlaştırılan dersler (Bk. Cerîde-i İlmiyye, 51, s. 1239-40) birbirleriyle uyuşmadığ gibi, 1335-36 (1919-20) öğretim yılındaki son sınıf imtihanlarında yer verildiği açıkça belli olan derslerle de uyuşmamaktadır. Bk. Cerîde-i İlmiyye, 62, s. 1996.

6oBOA, BEO, nr. 4685/351319/1 (12 Şevval 1339/19 Haziran 1921). 
belirtilmiştir. ${ }^{61}$ Tahsisatı kesilen medresenin öğretim ve idarî kadrosunun maaşlarının ödenmemesi de eklenince bir an önce çözülmesi gereken konu, Meclis-i Vükelầya intikal etmiş ve meşihatın görüşünün alınmasına karar verilmiştir. ${ }^{62}$ Meclisin bu konuda istediği açılama ve bilgiyi hazırlamak üzere meşihatta fetva emininin başkanlığında kurulan komisyon tarafından hazırlanan raporda, son zamanlarda medreselerin sslahı konusunda yapılan çalışmalardan söz edilerek Medresetü'l-irşâd’ın varlığının devamına gerçekten ihtiyaç bulunduğu; ancak birtakım düzenlemelerin de yapılması gerektiği belirtilmiştir:

Gayeleri başka başka olmakla beraber hiçbiri müstağnen anh olmayan işbu müessesât-1 ilmiyyenin ân-1 tesislerinden son zamanlara kadar tarîk-i tekâmülde hatve-endâz-1 terakkiyât olduğu ihtiyâcât-1 dîniyye ve lavâzım-1 asriyyeyi tatmin edebilecek meslek-i mahsus erbâbı olan müftüleri, kadıları, müderrisleri, vâiz ve mürșitleri ihzar ve idâd ederek semerât-ı nâfia ve matlûbe iktitâfı zamanı mütekarrib bulunduğu sırada medâris-i mâruzadan elyevm Medresetü'l-irşâd namı verilen Medresetü'lvâizîn'in maksad-1 te’sisi başka mecralara sevkedilerek adem-i lüzumuna hükm ve muhassesât-ı kalilesi istiksar edilmeye başlanılmış ise de tabakāt-ı muhtelife-i halkın tenvir ve irşâdına kadir ve idrak ve ihataları nispetinde kendilerine ahkâm-1 İslâmiyye'yi telkin ve tebliğe ve tehzîb-i ahlâk ve tanzîm-i mişvâre bi-hakkın muktedir meslekten yetişmiş münevver vâiz ve nâsihlere her zaman ve mekân için şiddetle ihtiyaç hâsıl olmakta bulunması bu medresenin ilgasına değil belki bazı mertebe ıslah ve tensîkiyle ibkā ve ihyasına lüzum göstermektedir. ${ }^{63}$

Bunun üzerine Meclis-i Vükelâ, komisyonun raporu doğrultusunda, medresede yer verilen derslerden bir kısmının aynı zamanda diğer medreselerde de okutulmakta olduğunu dikkate alarak programdan çıkartılmasına, buna karşılık alınacak talebelerin diğer medreselerde kısmen tahsil görmüş talebelerden seçilmesine imkân verecek biçimde kayıt şartlarının yeniden düzenlenmesi için meşihat makamı ve Evkaf Nezâreti’nin çalışma yapmasına, ayrıca bu esnada görevine devam eden öğretim ve idare kadrosuna ücretlerinin ödenmesine karar vermiştir. ${ }^{64}$

61 BOA, BEO, nr. 4695/352112/3; nr. 4695/352112/2; nr. 4702/352593/6.

62 BOA, BEO, nr. 4702/352593/3; nr. 4702/352593/7; nr. 4702/352593/4; nr. 4699/352366/1;

$\mathrm{BOA}, \mathrm{MV}, 222 / 82$.

63 BOA, BEO, nr. 4702/352593/2; nr. 4702/352593/5.

64 BOA, MV, 222/214, 223/39, 223/151. 
1922 yılı başında meşihatta fetva emini başkanlığında kurulan komisyon, Evkaf Nezâreti’nin vurguladığı malî yetersizlikleri dikkate alarak medresenin yapısında birtakım düzenlemeler yapmıştır. Bu çerçevede daha önce yirmi iki olan ders sayısı on bire, ilk kurulduğunda dört yıl olan öğretim süresi önce üç, daha sonra iki yıla düşürülmüştür. İdarî ve öğretim kadrosunun maaşlarında yapılan düzenlemelerle birlikte, ilk kurulduğunda 50.850 kuruş olan aylık giderleri 22.300 kuruşa düşürülmüştür. ${ }^{65}$ Hazırlanan nizamnâme Şubat 1922 tarihinde uygulanmak üzere Evkaf Nezâreti’ne gönderilmiştir. ${ }^{66}$ Ancak Evkaf Nezâreti konuyla ilgili olarak sadârete verdiği Ekim 1922 tarihli cevapta, nizamnâmede belirtilen derslerin büyük bir kısmının diğer medreselerde okutulduğundan söz ederek, programın "ayrıca bir medrese küşadı suretiyle tedrisi”ni önermiştir. ${ }^{67}$ Sonuç olarak malî yükü dolayısıyla medresenin eğitime devamını uygun görmeyen evkaf, şayet ısrar ediliyorsa malî yükü de meşihata ait olacak başka bir medresenin açılmasını istemektedir. Bu karar kurumun geleceğini belirlemiştir. Nitekim medresenin idaresinde etkili olan Dârü'l-hikmeti'l-İslâmiyye'nin 21 Ekim 1922 tarihinde son toplantısını yapması ${ }^{68}$, medresenin sadece malî değil idarî açıdan da sahipsiz kaldığını, kurumun resmen değilse de fiilen kapandığını göstermektedir.

1923 yllında Şer'iye Vekâleti Tedrisat Müdür-i Umûmîliği görevinde bulunan Ahmet Hamdi (Aksekili) Medresetü'l-irşâd hakkında hazırladığı raporda, medresenin mevcut durumu hakkında bilgi vermektedir. Raporda belirtildiğine göre, medreseye ilk açıldığında 150 talebe kabul edildiği halde bunların büyük kısmı henüz tahsillerini tamamlayamadan I. Dünya Savaşın'nda şehit olmaları yüzünden medrese sarsıntı geçirmiştir. Daha sonra medresenin bir yıl kapalı kalmasıyla durum daha da kötüleşmiştir. Medreseden mezun olan kırk talebeden ancak yedi-sekiz kadarına görev verilebilmesi yüzünden, diğerleri sefalet ve perişanlık içine düşmesi medreseye ilgiyi iyice azaltmış, Hutabâ ve Eimme Şubesi neredeyse kapanacak hale gelmiştir. ${ }^{69}$ Kurumun istenilen seviyeye gelebilmesi için öncelikle maddî sıkıntıdan

65 BOA, BEO, nr. 4702/352593/11. 66 BOA, BEO, nr. 4702/352593/12. $67 \mathrm{BOA}, \mathrm{BEO}, \mathrm{nr} .4702 / 352593 / 15$. 68 Akman, Osmanlı Devletinin Son Döneminde Bir Üst Kurul, s. 66.

69 Ahmet Hamdi, "Medresetü'l-irşâd”, s. 142-44. 1921 tarihli kayıtta medresenin Vâizîn Şubesi’nden altı, Eimme ve Hutabâ Şubesìnden ise bir talebe mezun olmuştur. Bunun dışında Vâizîn Şubesi 1 ve 2. sınıftan ikişer öğrenci sınıfı geçerken sekizer talebe ikmale kalmış, Eimme ve Hutabâ Şubesi’nde ise bir talebe sınıfı geçmiştir. Bk. Cerîde-i İlmiyye, 71, s. 2311. Buna göre, söz konusu dönemde mezun olanlarla birlikte medresede toplam yirmi sekiz öğrenci bulunmaktadır. 
kurtarılması ve programının amacına göre yeniden düzenlenmesi gerektiğini belirten Ahmet Hamdi'ye göre medrese, Anadolu'nun önemli bir merkezine taşınmalıdır. Vâizler Şubesi’ne yüksek dereceli medrese mezunlarından her yıl yirmi, Eimme ve Hutabâ Şubesine ise on talebe kabul edilmeli, mezunlardan vâizler İstanbul'daki büyük camilerden ziyade Anadolu'da, imam ve hatipler ise kendi memleketlerinde, yeterli birer maaşla görevlendirilmelidir. Ancak rapor, gerçekleştirilme imkânı bulamadan yaklaşık bir yıl sonra medreseler kapanmıştır. Ahmet Hamdi, Kurtuluş Savaşı̉nın devam ettiği yıllarda raporunu hazırladığı sırada kurumun geleceğini belirleyen, yukarıda yer verdiğimiz gelişmelerden muhtemelen haberdar değildir.

\section{Sonuç}

II. Meşrutiyet dönemindeki medrese sslah çalışmaları, medrese tarihimizde önemli bir dönüm noktası olmuştur. Bu dönemde klasik medrese yapısı değiştirilerek, mekteplerdeki yapıya benzer ve maarif sistemiyle uyumlu yeni bir yapının oluşturulması amaçlanmıştır. Bunun için medrese öğretimi derecelere ve basamaklara ayrılmış, programlar ve idarî yapı yeniden düzenlenmiştir. Söz konusu değişimin temel amaçları yeni sisteme uyum sağlamak ve din hizmetlerini yerine getirecek kalifiye personelin yetiştirilmesi olarak belirlenebilir. Oluşturulan bu yapı içerisinde açılan hem Dârü'l-hilâfeti'l-aliyye Medresesi hem de bu çalışmada ele aldığımız diğer medreselerin asıl amacı, din hizmetleri alanında istihdam edilecek imam, hatip, müezzin ve vâiz gibi görevlilerin yetiştirilmesidir. Sözü edilen görevlilerin yetiştirilmesi için ayrı kurumların açılması bu döneme has bir uygulamadır. Bu sebeple amaçları aynı olmasına rağmen niçin böyle bir çeşitliliğin ortaya çıtığ konusunun değerlendirilmesi gerekir.

Böyle bir uygulamaya gidilmesiyle medreselerin içinde bulunduğu durum, din hizmeti veren görevlilerinin yeterliliği ve yaşanan siyasî olaylar arasında ilişki kurulabilir. Batı'daki gelişmeler karşısında Osmanlı toplumunun içinde bulunduğu eğitim düzeyinin yükseltilmesi amacıyla Tanzimat sonrasında önemli adımların atılmış, medreseler ise bu gelişmelerin dışında kalmıştır. Bu durum özellikle II. Abdülhamid döneminden itibaren ulemâ ve devlet adamlarının gözünden kaçmamış, problem olarak belirlenmiş ve çözümü için birtakım çalışmalar yapılmıştır. Konu II. Meşrutiyet yıllarında daha kapsamlı olarak ele alınmıştır. Bu kapsamda, medreselerin ve din görevlilerinin başarısı ve yeterliliği tartışılıp eksiklikler dile getirilirken, diğer taraftan da eksikliklerin giderilmesi için çalışmalar yapılmıştır. Klasik medrese eğitiminin ve bilgi birikiminin bilimsel gelişmeler karşısında yetersiz 
kalması yanında, yaşanan savaşlar ve siyasî çalkantılar, dinî bilginin yaygınlaştırılması ve ülkede millî birliğin sağlanmasında mânevî desteğin önemine duyulan ihtiyaç, halkın karşısına çıkacak din görevlilerinin daha farklı ve kapsamlı biçimde eğitilmeleri gerektiği kanaatini güçlendirmiştir. Bu düşüncelerle Dârü'l-hilâfeti'l-aliyye Medresesi yanında, çalışmada ele aldığımız diğer medreseler açılmıştır.

Meslek medreseleri olarak kabul ettiğimiz bu medreselerin beklenen ölçüde verimli olamadığı, uygulanmasında başarı sağlanamadığı görülmektedir. Bunun sebepleri arasında siyasî belirsizlikler ve savaş yıllarına rastlamış olmasının yanında kurumların idarî birliğinin sağlanamamasının da çok önemli payı olmuştur. Diğer taraftan temel bilgi alanı aynı olan mesleklerin eğitiminin farklı kurumlarda yapılması emek, zaman ve kaynak artışına, ayrıca idarî açıdan güçlüklere sebep olan gereksiz bir kurumsal çeşitlenmeye, bunun da "amaç" ve "gerekliliği izah" konusunda ikna edici olmaktan uzak kaldığı görülmektedir. Başka bir ifade ile müftü, vâiz, imam gibi din görevlilerinin temel eğitimlerini aynı kurumda aldıktan sonra şayet hizmet alanlarıyla ilgili farklı eğitimleri gerekiyor ise bunu ya aynı kurumda farklı ders veya bölümler altında ya da hizmet esnasında tamamlamaları daha anlamlı görünmektedir. Günümüz açısından da bu husus göz önünde tutulması gerekir. Kurumlardaki çeşitlilik yerine amaca uygun program, müfredat ve yöntemlerin geliştirilmesi daha yararlı olacaktır.

Tevhîd-i Tedrîsat Kanunu'nda sözü edilen "imâmet ve hitâbet gibi hidemât-1 dîniyyenin îfâsı vazifesiyle mükellef memurların yetişmesi” amacryla açılan İmam ve Hatip mekteplerinin programları hazırlanırken II. Meşrutiyet yıllarında açlan medreselerin programları model alınmıştır; ancak öğretimin dereceleri, basamakları ve aralarındaki geçiş yanında öğretim süresi konusunda model olma ancak 1950 sonrası için söz konusu olabilir. Bu dönemden itibaren orta ve yüksek derecelerde, aralarındaki süreklilik sağlanarak gelişen meslekî din eğitimi kurumlarımızın din görevlisi yetiştirebilme yeterliliklerinin arttırılması için, isimlerinin değiştirilmesi değil, belirlenen yeterlilikleri gerçekleştirebilecek program, müfredat ve yöntem farklılıklarıyla zenginleştirilen yapıların oluşturulması gerekir. 


\section{Bibliyografya}

\section{A. Arşiv Kaynakları}

BOA (Başbakanlık Osmanlı Arşivi), A. AMD (Amedî Kalemi Evrakı) 1/2; 31/20.

BOA, A. MKT. MHM (Mühimme Kalemi Evrakı), 213/8.

BOA, A. DVN (Divan Kalemi Evrakı), 48/2.

BOA, BEO (Bâb-1 Âlî Evrak Odası), nr. 1770/132691; nr. 4685/351319/1; nr. 4695/352112/2, 3; nr. 4699/352366/1; nr. 4702/352593/2, 3, 4, 5, 6, 7, 9, 11, $12,15$.

BOA, C. MF (Cevdet-Maarif), 7594.

BOA, DH. EUM. THR (Tahrirat Kalemi), 91/15.

BOA, Dîvân-ı Hümâyun Ruûs Defterleri, Medâris-i Âsitâne-i Âliye, nr. 224.

BOA, MV (Meclis-i Vükelâ), 143/38, 163/79, 222/82, 222/214, 223/39, 223/151, 233/98, $250 / 72$.

BOA, ŞD (Şûrâ-y1 Devlet), 207/36, 2842/55.

BOA, Y. EE (Yıldız Esas Evrakı), 5/119, 38/14, 15.

BOA, Y. PRK. BŞK (Yıldız Parakende Baş Kitâbet Ma'rûzâtı), 25/85, 30/19.

BOA, Y. MŞ (Yıldız Parakende Meşîhat Dairesi Ma'rûzâtı), 6/2.

BOA, Y. MTV (Yıldız Mütenevvi Ma'rûzât), 25/52.

BOA, ZB (Zaptiye Nezâreti), 350/123.

İstanbul Müftülüğü Şer'iyye Sicilleri Arşivi, Eimme ve Hutabâ Şubesi Yoklama Defteri, sene 1335-40 (1919-24), nr. 2338; Medresetül-hutabâ Talebesinin Künye Defteri, nr. 2339; Medresetü’l-irşâd Vâizîn Şubesi Talebe Efendilerin Künye Defteri, nr. 2343.

\section{B. Diğer Kaynaklar}

Ahmet Hamdi (Aksekili), “Medresetü’l-irşâd”, Sebîlürreşâd, 21/538-539 (1339): 142-44. Ahmet Necati, “Ulemâ-i Kiramdan Bir Rica”, Beyânülhak, 171 (1330): 3009-10.

Akgündüz, Ahmet, "Muhammed Abduh'un Gözüyle Osmanlı Devleti ve Eğitim Sistemi”, Sur, 141 (1987): 34-41.

Akgündüz, Murat, Osmanlı Döneminde Vâizlik, İstanbul: Osmanlı Araştırmaları Vakfl, 2016.

Akman, Zekeriya, Osmanl Devletinin Son Döneminde Bir Üst Kurul Dâru'l-Hikmetilİslâmiye (1918-1922), Ankara: Diyanet İşleri Başkanlığı, 2009.

"Alay ve Tabur İmamlarının Vezâif-i Tedrisiyeleri Hakkında Nizamnâme", Düstûr, İkinci tertip, İstanbul: Matbaa-i Âmire, 1334, VI, 332-33.

Başkurt, İrfan, “Osmanlı'dan Cumhuriyet'e Kürsü Şeyhliği”, İslâmî Araştırmalar, 27 (2012): 117-45.

Bayraktar, M. Faruk, Türkiye'de Vâizlik (Tarihçesi ve Problemleri), İstanbul: Marmara Üniversitesi İlâhiyat Fakültesi Vakfı, 2016. 
Beydilli, Kemal, Osmanlılar Döneminde Imamlar ve Bir İmamın Günlüğü, İstanbul: Tarih ve Tabiat Vakf1, 2001.

Cerîde-i İlmiyye, 1 (1332), s. 18-19; 8 (1333), s. 516-17; 9 (1333), s. 573-76; 48 (1337), s. 1515-16; 51 (1338), s. 1239-40; 62 (1338), s. 1995-96; 71 (1340), s. 2311.

"Cevâmi' ve Mesâcîd-i Şerîfede Vaaz ve Nasihat Edecek Ulema Hakkında Nizamnâme", Düstûr, İkinci tertip, İstanbul: Matbaa-i Âmire, 1334, VI, 18-19.

Doğan, Recai, "Yaygın Din Eğitimi Açısından İkinci Meşrutiyet Dönemine Kadar Vaaz ve Vâizliğin Gelişimine Tarihi Bir Bakış”, Dinî Araştırmalar, 1/3 (1999): 257-72.

Ergün, Mustafa, “II. Meşrûtiyet Döneminde Medreselerin Durumu ve Islahat Çalışmaları”, Ankara Üniversitesi Dil ve Tarih-Coğrafya Fakültesi Dergisi, 30/1-2 (1982): 59-89.

İlmiyye Salnamesi, İstanbul: Matbaa-i Âmire, 1334.

Kanal, Hümmet, "II. Abdülhamit Devrinde İstanbul Medreselerindeki Öğrencilerin Cerr Faaliyetleri”, Avrasya Incelemeleri Dergisi, 3/2 (2014): 251-94.

Kazıcı, Ziya - Mehmet Şeker, İslam-Türk Medeniyeti, İstanbul: Çağrı Yayınları, 1982.

Kodaman, Bayram, Abdülhamit Devri Eğitim Sistemi, İstanbul: Ötüken Yayınları, 1980.

Kurşun, Zekeriya v.dğr., Medâris-i İstanbul: Yaşayan İstanbul Medreseleri, I-II, İstanbul: İstanbul Büyükşehir Belediyesi, 2008.

Kütükoğlu, Mübahat, XX. Asra Erişen İstanbul Medreseleri, Ankara: Türk Tarih Kurumu, 2000.

“Medresetü'l-vâizîn”, Sebîlürreşâd, 11/273 (1329): 194-95.

Medresetü'l-vâizîn Nizamnâme ve Tâlimatnâmesi, İstanbul: Matbaa-i Âmire, 1332.

“Medresetü’l-vâizîn Nizamnâmesi”, Düstûr, İkinci tertip, İstanbul: Matbaa-i Âmire, 1334, VI, 212-15.

Mustafa Hakk1, “Ulemâ-yi İslâmiyye ile Hasbihal”, Beyânülhak, 34 (1327): 795-96.

Mustafa Hakk1, "Vâizîn-i Kirâm İçin Vezâif-i Mühimme”, Beyânülhak, 37 (1327): 854-57.

Mustafa Sabri, “Talebe-i Ulûma”, Beyânülhak, 33 (1327): 764-68.

Reşid Rıza, “Meşrutiyet İstanbul'una Seyahat ve Dâru’l-İlm ve’l-İrşâd Projesi”, çev. İrfan İnce, İstanbul Araştırmaları, 5 (1998): 163-87.

Sarıkaya, Yaşar, Medreseler ve Modernleşme, İstanbul: İz Yayınları, 1997.

“Talebe-i Ulûm Mahsûsâtına Dair Nizamnâme”, Takvîm-i Vekāyi', 684 (1326): 2-3.

“Tevcîh-i Cihât Nizamnâmesi”, Düstûr, İkinci tertip, İstanbul: Matbaa-i Osmâniyye, 1332, V, 608-17.

Uzunçarşılı, İ. Hakkı, Osmanlı Devletinin İlmiye Teşkilâtı, Ankara: Türk Tarih Kurumu, 1988.

"Vâizlere İhtar", Beyânülhak, 39 (1327): 877-79.

Yazıcı, Nesimi, "Osmanlıların Son Döneminde Din Görevlisi Yetiştirme Çabaları Üzerine Bazı Gözlemler”, Diyanet Dergisi, 27/4 (1991): 55-123. 


\section{Osmanlılar'da II. Meşrutiyet Döneminde Yeni Açılan Medreseler ve Din Gö- revlisi Yetiştirme Çalışmaları}

Osmanlı eğitim sistemi Tanzimat yıllarından itibaren değiştirilerek, medreselerin dışında yeni bir anlayış ve teşkilât ile farklı bir eğitim sistemi kurulmuştur. 1857 yılında Maârif-i Umûmiyye Nezâreti’nin kurulmasından sonra yeni eğitim teşkilâtı hızla gelişmiş, genel eğitim tamamen çeşitli derecelerde açılan mekteplerin faaliyet alanına girmiştir. Bu gelişme karşısında, medreselerin faaliyet alanı büyük oranda din ilimlerinin öğretimiyle buna bağlı olarak din hizmetlerini yerine getirecek görevlilerin yetiştirilmesiyle sınırlı kalmıştır. Ortaya çıkan bu durum karşısında medreselerin söz konusu amaçlarını daha etkili biçimde gerçekleştirmeleri için eğitim anlayış ve teşkilâtının gözden geçirilerek birtakım yeni düzenlemelerin yapılması gerekmiştir. Tanzimat ve II. Abdülhamid dönemlerinde medrese sisteminde düzenlemeler yapılması gerektiği dile getirilmiş; hatta bazı girişimler yapılmış olsa da geleneksel yapısını korumaya devam etmiştir. Medreselerin yeni eğitim sistemiyle uyumlu olarak yeniden düzenlenmesi II. Meşrutiyet döneminde gerçekleştirilmiştir.

Medreselerin ıslahı iki temel amaca dayanmaktadır: İlki medreselerin yeni eğitim sistemine uyumunun sağlanması diğeri ise medreselerdeki eğitim kalitesinin yükseltilerek nitelikli din görevlilerinin yetiştirilmesi. Bu amaçla genel medreselerin dışında, imam, hatip, vâiz gibi din görevlilerinin eğitilmesini amaçlayan yeni medreseler de açılmıştır. Bu medreseler, dönem boyunca yapılan düzenlemelerle Medresetü'l-irşâd adıyla birleştirilmiştir. Ancak Osmanlı Devleti’nin I. Dünya Savaşı'na girmesinden sonra yaşanılan buhran ile medresenin idarî ve malî yapısındaki anlaşmazlıklar sebebiyle girişim başarıya ulaşamamıştır. Bununla birlikte dönem boyunca yapılan çalışmalar Cumhuriyet döneminde aynı amaçla açılan kurumlara örnek teşkil etmiştir. Diğer taraftan, çalışmalar esnasında atılan adımlar ve bunların sonuçlarının oluşturduğu birikim günümüzde aynı konuda yapılan ve yapılacak çalışmalar açısından da değer taşımaktadır. Makale, tarihî bir vakanın tanıtımıyla birlikte yaşanan tecrübenin günümüzde yapılacak çalışmalara yansıtılmasını amaçlamaktadır.

Anahtar kelimeler: Osmanlı Devleti, II. Meşrutiyet dönemi, Medresetü’l-vâizîn, Medresetü'l-irşad, Medresetü'l-eimme ve'l-hutabâ, din görevlisi. 
